\title{
Complex adaptive immunity to enteric fevers in humans: lessons learned and the path forward
}

\section{Marcelo B. Sztein*, Rosangela Salerno-Goncalves and Monica A. McArthur}

Department of Pediatrics, Center for Vaccine Development (CVD), University of Maryland School of Medicine, Baltimore, MD, USA

\section{Edited by:}

Constantino López-Macías, Mexican Social Security Institute, Mexico; University of Oxford, UK

\section{Reviewed by:}

Adam Cunningham, University of Birmingham, UK

Armando Isibasi, Mexican Social

Security Institute, Mexico

*Correspondence:

Marcelo B. Sztein, Department of Pediatrics, Center for Vaccine Development (CVD), University of Maryland School of Medicine, 685 West Baltimore Street, HSF 480,

Baltimore, MD 21201, USA

e-mail:msztein@medicine. umaryland.edu
Salmonella enterica serovar Typhi (S. Typhi), the causative agent of typhoid fever, and $S$. Paratyphi A and B, causative agents of paratyphoid fever, are major public health threats throughout the world. Although two licensed typhoid vaccines are currently available, they are only moderately protective and immunogenic necessitating the development of novel vaccines. A major obstacle in the development of improved typhoid, as well as paratyphoid vaccines is the lack of known immunological correlates of protection in humans. Considerable progress has been made in recent years in understanding the complex adaptive host responses against $S$. Typhi. Although the induction of $S$. Typhi-specific antibodies (including their functional properties) and memory B cells, as well as their cross-reactivity with $S$. Paratyphi A and S. Paratyphi B has been shown, the role of humoral immunity in protection remains undefined. Cell mediated immunity (CMI) is likely to play a dominant role in protection against enteric fever pathogens. Detailed measurements of CMI performed in volunteers immunized with attenuated strains of $S$. Typhi have shown, among others, the induction of lymphoproliferation, multifunctional type 1 cytokine production, and CD8 ${ }^{+}$ cytotoxic T-cell responses. In addition to systemic responses, the local microenvironment of the gut is likely to be of paramount importance in protection from these infections. In this review, we will critically assess current knowledge regarding the role of $\mathrm{CMI}$ and humoral immunity following natural $S$. Typhi and $S$. Paratyphi infections, experimental challenge, and immunization in humans. We will also address recent advances regarding cross-talk between the host's gut microbiota and immunization with attenuated $S$. Typhi, mechanisms of systemic immune responses, and the homing potential of $S$. Typhi-specific B-and T-cells to the gut and other tissues.

Keywords: Salmonella Typhi, Salmonella Paratyphi, enteric fever, typhoid fever, human immunity, CMI, multifunctionalT-cells, microbiota

\section{INTRODUCTION}

Enteric fevers encompass typhoid fever caused by the Gramnegative intracellular bacterium Salmonella enterica serovar Typhi (S. Typhi) and paratyphoid fever caused largely by $S$. enterica serovars Paratyphi A and B (S. Paratyphi) $(1,2)$. Most cases of enteric fever are caused by $S$. Typhi (3). However, infections caused by $S$. Paratyphi A have been increasing in recent years, particularly in Asia $(2,4-7)$. Typhoid and paratyphoid fevers are life-threatening illnesses exhibiting very similar clinical features $(2,8)$. Humans are the only reservoir for these infections. The disease spreads by the fecal-oral route via contaminated food and water (9). In industrialized countries, enteric fevers are rare with most infections occurring in military personnel and in individuals traveling to endemic areas. According to the $\mathrm{CDC}$, in the United States, it is estimated that $\sim 5,700$ cases of $S$. Typhi infection occur annually, mostly acquired while individuals are traveling internationally. However, S. Typhi and S. Paratyphi infections are a major public health problem in the developing world (9-13). It is estimated that 26.9 million new cases of typhoid fever occur annually with about $1 \%$ mortality (9-13). Based on data provided by the World Health Organization, $90 \%$ of these typhoid deaths occur in Asia, and most victims are children under 5 years of age
(14). Furthermore, antimicrobial treatment of enteric fever and asymptomatic carriers has become increasingly complicated due to the emergence of multidrug-resistant strains of $S$. Typhi and $S$. Paratyphi A $(7,15,16)$. Thus, there has been an increased emphasis on control measures, such as improved sanitation, food hygiene, and vaccination $(8,10,17)$. It has also become evident that a better understanding of the host immune responses against $S$. Typhi and $S$. Paratyphi are required. This review will focus on the adaptive human immune responses [i.e., humoral and cell mediated immunity (CMI)] to $S$. Typhi and S. Paratyphi acquired through natural infection, experimental challenge, and vaccination. For discussions of the "mouse model of Salmonella infection," the reader is referred to excellent reviews included in this "Frontiers in Immunology Research Topic" compilation.

\section{IMMUNITY ELICITED IN NATURAL INFECTIONS CAUSED BY} S. Typhi AND S. Paratyphi

Salmonella Typhi is a facultative intracellular bacterium that causes an acute generalized infection of the reticuloendothelial system (RES), intestinal lymphoid tissue, and gallbladder in humans (18). Classical symptoms include gradual onset of sustained fever, chills, hepatosplenomegaly, and abdominal pain. In some cases, 
patients experience rash, nausea, anorexia, diarrhea, or constipation, headache, relative bradycardia, and reduced level of consciousness (19). After S. Typhi ingestion, the period of incubation ranges from 3 to 21 days, with the mean incidence between 8 and 14 days (19). Without effective treatment, typhoid fever has a casefatality rate of $10-30 \%$. This number can be reduced to $1-4 \%$ with appropriate therapy (10). In addition, a small number of individuals become "carriers." These individuals, after recovering from acute $S$. Typhi infection, keep shedding $S$. Typhi in their feces and are able to spread the disease.

After ingestion of contaminated food or water, sufficient numbers of $S$. Typhi might survive the low $\mathrm{pH}$ of the stomach and cross the intestinal epithelial monolayer through mechanisms that involve $\mathrm{M}$ cells, dendritic cells (DC), passage through enterocytes in endocytic vacuoles, and/or disruption of tight junctions (paracellular route) $(20,21)$. Once in the lamina propria, $S$. Typhi can spread systemically and trigger innate and adaptive host immune responses.

Most of our knowledge of adaptive host immune responses to $S$. Typhi natural infection originates from studies involving individuals living in typhoid endemic areas (21-23). Clinical studies indicate that the development of protective immunity after recovery from typhoid fever is possible but that the frequency of individuals able to mount protective immune responses is low $(22,23)$. S. Typhi infections in individuals living in endemic areas elicit the appearance of both humoral and CMI responses. AntiS. Typhi-specific antibodies against lipopolysaccharide (LPS), H (flagellin), Vi ( $S$. Typhi capsular polysaccharide; virulence factor), porins, and heat-shock proteins (e.g., GroEL), among others, have been well documented in the sera of acute and convalescent typhoid fever patients (24-31). In addition, the presence of anti-S. Typhi secretory IgA (SIgA) was also described in intestinal fluids of typhoid patients (32). Of note, high-anti-Vi IgG antibodies are present in a considerable proportion of chronic biliary $S$. Typhi carriers, particularly in endemic areas. The presence of functional antibodies against $S$. Typhi (e.g., bactericidal activity), which increase with age has also been reported in healthy residents of typhoid endemic areas (33). However, the role that antibodies play in protection remains elusive. For example, susceptibility to typhoid infection has been reported to occur despite the presence of elevated titers of antibodies against $\mathrm{O}, \mathrm{H}$, and other S. Typhi antigens $(22,23,29,34)$.

Clinical observations suggest that CMI, particularly cytokines, play an important role in host defense against Salmonella infection. For example, increased susceptibility to invasive Salmonella infections, caused largely by non-typhoidal Salmonella, as well as a few $S$. Typhi and $S$. Paratyphi cases, have been reported in individuals with immune deficiencies for interferon (IFN) $-\gamma$, interleukin (IL)-12, IL-23, and STAT1 receptors (35-38). Moreover, significant genetic associations were reported between susceptibility or resistance to typhoid fever and HLA-DR and HLA-DQ MHC and tumor necrosis factor (TNF)- $\alpha$ alleles in Vietnam residents (39). Of note, although the data is sparse, it has been reported that human immunodeficiency virus (HIV) positive patients in an endemic area are at significantly increased risk for infection with S. Typhi and S. Paratyphi (40). However, these results will need further confirmation as other studies have failed to observe this association (36).

The importance of CMI in the host's response to $S$. Typhi has also been derived from early studies in acute and chronic carrier typhoid patients, which demonstrated the presence of specific CMI responses, including antigen-specific lymphoproliferation, leukocyte migration inhibition, and rosette-forming cells $(32,41-$ 46). Moreover, elevated serum levels of IFN- $\gamma$, IL-6, and TNF- $\alpha$ receptor (TNF-R) p55 and TNF-R p75 were reported in S. Typhi and S. Paratyphi A-infected patients in Nepal (47). Interestingly, in these studies higher values of IL-6 and soluble TNF-R p55 were related to poorer outcome. In another study, Keuter et al. showed that levels of the anti-inflammatory mediators IL-1 receptor antagonist (IL-1RA), soluble TNF-R (p55 and p75), and IL-8 were higher in the acute phase than in the convalescent phase (48). In contrast, the production capacity of pyrogenic cytokines (TNF, IL-6) was depressed in the acute phase of typhoid fever but was restored during the convalescent phase. Of note, no differences were observed between patients with complicated or uncomplicated disease courses. These observations have been extended by recent studies in Bangladeshi typhoid patients, which have shown the induction of specific T-cell responses [e.g., production of IFN- $\gamma$, IL-17, macrophage inflammatory protein (MIP)-1 $\beta$, lymphoproliferation] to purified $S$. Typhi antigens using a novel highthroughput technique (49-51). Concerning the cellular source of cytokines/chemokines, experiments using human PBMC from healthy subjects and Ty21a vaccinees have shown that, in addition to lymphocytes, stimulation with $S$. Typhi flagella induced the rapid de novo synthesis of TNF- $\alpha$ and IL- $1 \beta$, followed by IL- 6 and IL-10 in macrophages (52). Follow-up experiments indicated that whole-cell $S$. Typhi and $S$. Typhi flagella also have the ability to downregulate in vitro lymphocyte proliferation to soluble antigens and mitogens by affecting macrophage function, suggesting that $S$. Typhi components have the potential to exert both up-regulatory and down-regulatory effects on the host immune response (53). Taken together, these observations suggest that although antibodies are likely to participate in protection against typhoid fever, CMI probably represent the dominant protective immune responses that eventually lead to the elimination of these bacteria from the host.

More limited information is available regarding immunological responses in paratyphoid fever. Several reports showed the presence of serological responses against LPS and H-flagellar $S$. Paratyphi antigens using the Widal, colorimetric, and ELISA tests $(7,54)$. More recently, immunogenic S. Paratyphi A proteins expressed in bacteremic S. Paratyphi A-infected individuals have been identified using an immunoscreening technique (IVIAT; in vivo-induced antigen technology) (4). These studies identified several S. Paratyphi A proteins expressed in vivo ( 20 proteins, including those involved in pathogenesis, such as fimbria, cell envelope and membrane structures, energy metabolism, and cellular proteases), which elicited antibody responses in these patients during the acute and convalescent phases. These results confirmed and extended previous studies by the same group using a different technique (SCOTS, selective capture of transcribed sequences) in Bangladeshi patients who were bacteremic with S. Paratyphi A and 
S. Typhi $(51,55)$. Taken together, these observations highlight several S. Paratyphi A proteins, which might play an important role in S. Paratyphi A pathogenesis and which may serve as targets of upcoming vaccine development efforts.

Regarding CMI, as reported in typhoid fever, elevated serum levels of IFN- $\gamma$, IL-6, TNF-R p55, and TNF-R p75 were reported in S. Paratyphi A-infected patients (47). Moreover, a very recent manuscript described the induction of serum pro-inflammatory cytokines in Israeli travelers who became infected with $S$. Paratyphi A while visiting Nepal (6). These studies showed elevated serum levels of both pro-inflammatory and anti-inflammatory cytokines/chemokines during the acute phase, including IFN- $\gamma$, IL-6, IL-8, IL-10, IL-15, and TNF- $\alpha$. Of note, no changes were observed in the serum levels of the other cytokines evaluated in these studies (i.e., IL-1 $\alpha$, IL-1 $\beta$, IL-2, IL-4, IL-5, IL-12p70, IL-13, IL-17, IL-23, and TNF- $\beta$ ). These increases in pro-inflammatory cytokines/chemokines observed in S. Paratyphi A infections are similar to those reported in typhoid fever, supporting the contention that similar host immune responses might be elicited in enteric fevers caused by $S$. Typhi and $S$. Paratyphi bacteria. Interestingly, elevated serum levels of pro-inflammatory (IFN- $\gamma$, IL-12, and TNF- $\alpha$ ) cytokines but decreased levels of IL-10 were reported in patients with early non-typhoidal gastroenteric Salmonella bacterial clearance in stools as compared to the non-clearance group (56). It is reasonable to speculate that these observations demonstrating the increased circulating levels of both pro-inflammatory and anti-inflammatory cytokines/chemokines suggest the concomitant presence of both $\mathrm{T}$ effector $\left(\mathrm{T}_{\text {eff }}\right)$ and $\mathrm{T}$ regulatory $\left(\mathrm{T}_{\text {reg }}\right)$ responses following wild-type infection.

Another issue to consider regarding the cytokine/chemokine data in natural infections with typhoidal and non-typhoidal Salmonella is that although increases in circulating cytokines/ chemokines are widely considered to be associated with protective responses, this might not necessarily be an accurate interpretation. In fact, it is likely that the levels of cytokines/chemokines in the microenvironments of the gut and the "RES" (e.g., regional lymph nodes, spleen, and other secondary lymphoid tissues) are not necessarily reflected in circulation. These are the sites in which most immune responses are likely to be generated, and where Salmonella find their niche(s) for long-term persistence, representing important sites for localized immune responses. With the information currently available, it is not possible to rule out the notion that serum/plasma levels might be a representation of a generalized pro-inflammatory response (part of the so called "cytokine storm," a surrogate marker of inflammation) in response to a systemic bacterial infection (e.g., the host's response to LPS and other bacterial antigens) rather than an effective targeted host response leading to protection.

\section{IMMUNITY ELICITED BY EXPERIMENTAL CHALLENGE WITH WILD-TYPE $S$. TYPhi (CONTROLLED HUMAN INFECTION MODEL; TYPHOID CHI)}

$S$. Typhi is a human-restricted pathogen, i.e., there are no good animal models that faithfully recapitulate $S$. Typhi infection (57). To partially address this shortcoming, the infection of susceptible mice with $S$. Typhimurium has been used as a model for the pathogenesis of human typhoid fever (57). Although these murine models have provided considerable knowledge regarding host-pathogen interactions, they do not fully represent $S$. Typhi infection in humans (58). Furthermore, the recent availability of full genome sequences from various $S$. enterica serovars have uncovered many differences in inactivated or disrupted genes, which can explain, at least in part, the dissimilarities observed in the immune and other host responses to these enteric bacteria (58). Thus, controlled human infection (CHI, "challenge") studies in which subjects are exposed orally to wild-type $S$. Typhi, have the potential to provide a better understanding of the human immune response to infection. Additionally, these studies have the capacity to uncover the correlates of protection against $S$. Typhi, which might prove critical to accelerate the development of better and more effective vaccines to prevent typhoid and other enteric fevers $(59,60)$.

While challenge experiments with virulent $S$. Typhi were reported early in the twentieth century (59), University of Maryland Researcher, Dr. Theodore E. Woodward, is considered the pioneer in the establishment of a reproducible challenge model (61). In this challenge model, participants were orally challenged with wild-type $S$. Typhi suspended in milk, without buffer. In his first challenge assay performed in the 1950s, Dr. Woodward used the wild-type strain Ty2 isolated from an outbreak in Kherson (in modern day Ukraine) in 1918 (62). All subsequent challenge assays were performed using the Quailes strain, which was isolated from the gallbladder of a chronic carrier, and demonstrated virulence through transmission to several household members (60). To highlight the importance of this challenge model, studies by Dr. Woodward and his collaborators at the University of Maryland led to the successful use of chloramphenicol in the treatment of patients with typhoid fever (61) and also served as the first step toward eventual licensure of the Ty21a typhoid vaccine (63).

Very recently, over three decades after the last human wild-type $S$. Typhi challenge study was performed at University of Maryland, Dr. Pollard's group in Oxford (UK) has re-established this model. This CHI model followed in the steps of previous studies by challenging healthy adult subjects with wild-type $S$. Typhi Quailes strain (63). However, the challenge agent was suspended in a sodium bicarbonate solution rather than milk. Two dose levels $\left(10^{3}\right.$ or $10^{4}$ colony-forming units) resulted in attack rates of 55 or $65 \%$, respectively. Interestingly, participants who developed typhoid infection demonstrated serological responses to flagellin and LPS antigens by day 14, while no changes were observed in the titers of these antibodies in participants not succumbing to infection after challenge. It is reasonable to speculate that the increased anti-LPS responses in subjects who developed typhoid was largely the result of clinical disease involving local and systemic infection rather than representing a protective mechanism at play. Moreover, anti-S. Typhi antibody baseline titers did not correlate with subsequent infection risk (63). These results are somewhat different than those from Maryland challenges in which anti-H antibodies appear to correlate with protection. Of note, in the Oxford CHI studies, antibody responses were not detected against $\mathrm{Vi}$, which is present in most $S$. Typhi isolates, including the Quailes strain. These results are in agreement with the Maryland challenge studies, which showed considerable increases in flagellin and LPS antibody titers soon after infection (during the incubation 
period) but only modest rises in anti-Vi antibody titers (64). Of note, clinical illness and relapse were reported in the Maryland challenge studies to occur at the peak of antibody responses (64). Taken in concert, these results suggest that anti-Vi and other anti$S$. Typhi-specific antibodies are likely to play a role in protection during natural infection. However, their precise contribution to host defense, either independently or in conjunction with other effector immune responses, remains to be established.

The Maryland CHI studies conducted in the 1950s, 1960s, and 1970 s did not address the role of CMI in protection against $S$. Typhi infection, primarily due to the lack of appropriate assays. It is likely, however, that the performance of in depth CMI studies with specimens obtained from subjects participating in the recently reestablished Oxford typhoid CHI model using the most advanced current techniques and instrumentation, will greatly advance our understanding of the role of CMI in protection.

\section{TYPHOID AND PARATYPHOID VACCINES: CURRENT STATUS}

The first typhoid vaccines consisting of inactivated (heat-killed, phenol-preserved) $S$. Typhi delivered parenterally were developed as far back as 1896 by Pfeiffer and Kolle in Germany and Wright in England (65). At that time, typhoid fever was a much-feared disease. However, following the discovery that antibiotics such as chloramphenicol could successfully treat typhoid fever, the interest in typhoid vaccines waned. A resurgence of interest in typhoid vaccines began in the 1970s, when epidemics of chloramphenicolresistant typhoid occurred in Mexico and Vietnam (1). Although inactivated whole-cell vaccines are immunogenic and effective, due to excessive reactogenicity, they are no longer manufactured (66-68). Currently, there are two vaccines against $S$. Typhi that are licensed in the USA for use in humans, the purified Vi ("virulence") polysaccharide parenteral vaccine and the oral live-attenuated $S$. Typhi strain Ty21a vaccine. Both vaccines are moderately protective and have been shown to induce herd immunity $(69,70)$. The Vi polysaccharide vaccine was developed by Robbins and collaborators at $\mathrm{NIH}$ as an injectable subunit vaccine and is currently sold by several companies, including Sanofi Pasteur and GlaxoSmithKline (Table 1) (69, 71-75). Although the Vi vaccine confers a moderate level (55-72\%) of protection in children over 2 years of age after a single dose, this vaccine does not confer "memory" and there are no robust data to suggest that the efficacy of Vi persists beyond 3 years $(66,67,69,76)$. The Ty21a vaccine, licensed for children older than 6 years, confers a moderate level of long-lived protection (60-80\%, 5-7 years) but requires the administration of three to four spaced doses $(66,70,77)$. Despite its moderate immunogenicity much of our knowledge regarding immunological responses against $S$. Typhi has been derived from studies of Ty21a immunization (Table 1) (52, 66, $67,78-92)$. Vaccination of children younger than 2 years old, however, requires a new approach. The $\mathrm{Vi}$-protein-conjugate vaccines appear promising in this regard $(14,93-96)$. Conjugate Vi vaccines consist of the S. Typhi Vi polysaccharide, a T-cell-independent antigen, covalently bound to a carrier protein. Hence, the conjugation process increases the immunogenicity of the vaccine by converting the Vi polysaccharide into a "T-cell-dependent" antigen. Various Vi-conjugate vaccine candidates are in development. For example, Vi O-Acetyl Pectin-rEPA conjugate vaccine, a modified conjugate vaccine where $\mathrm{Vi}$ is conjugated to nontoxic recombinant Pseudomonas aeruginosa exotoxin A (rEPA) has shown an efficacy of $\sim 90 \%$ in 2-5-year-old children (94, 96-99). Recently, Bharat Biotech in India has launched the world's first Viconjugate vaccine, called Typbar-TCV ${ }^{\mathrm{TM}}$, consisting of Vi from $S$. Typhi strain Ty2 conjugated to tetanus toxoid (TT) as a carrier protein, which can be given to infants older than 6 months $(100,101)$. Other vaccine candidates include Vi-conjugated to $\mathrm{CRM}_{197}$ (95) and diphtheria toxoid (102) (Table 1). Of note, issues that have been raised and merit consideration regarding the use of $\mathrm{Vi}$ and Vi-conjugate vaccines are the emergence of S. Typhi Vi antigennegative strains in multidrug-resistant typhoid fever cases and the possibility that the generalized use of Vi vaccines might lead to increased incidence of enteric fevers caused by Vi-negative strains for which Vi vaccines will be ineffective $(103,104)$. As a result of these issues, as well as other scientific, logistical, and economic reasons, additional subunit vaccine candidates are being actively developed for the prevention of enteric fevers. These include, among others, conjugates of $S$. Typhi and $S$. Paratyphi A LPS to carrier proteins or Salmonella proteins (e.g., flagellin, porins) to extend the generation of immunity to other relevant specific antigens (101).

Because of the above considerations, investigators, including those at the University of Maryland Center for Vaccine Development (CVD), have engineered new attenuated typhoid vaccine strains that aim to be as safe as Ty21a but immunogenic and protective following the ingestion of only a single dose. These vaccine candidates include Ty800 (113), M01ZH09 (114-120), and others based on attenuation of $S$. Typhi by deletions of genes such as those involved in the synthesis of aromatic amino acids ( aroC, aroD) and heat-shock proteins $(h t r A)$. The latter vaccine candidates, designated CVD 906 (105, 106), CVD 908 (107-109), CVD 908-htrA (110), and CVD 909 (112), have been evaluated in volunteers and shown to induce potent CMI both in vitro and ex vivo (83-85, $105,107,110-112,121-123)$, as well as humoral responses (105, 108, 110, 112) (see below for details). Except for CVD 906, these strains are derived from the wild-type $S$. Typhi Ty2 strain, the same strain from which the Ty21a vaccine was derived. Table 1 includes a summary of the characteristics of these typhoid vaccine strains and the documented immune responses elicited in volunteers.

Regarding $S$. Paratyphi vaccines, the first killed whole-cell parenteral typhoid vaccines produced a century ago consisted of a trivalent combination of heat-inactivated and phenol-preserved S. Typhi, S. Paratyphi A, and S. Paratyphi B (TAB vaccine) (67). Although this vaccine was moderately efficacious, its manufacture was discontinued due to high levels of reactogenicity (2). Although several vaccine candidates against enteric fever caused by $S$. Paratyphi A are at various stages of development, including S. Paratyphi A O-specific polysaccharide-TT and $\mathrm{CRM}_{197}$ conjugates (124-126), no vaccines are currently commercially available.

It is important to note that there has been considerable interest in exploring the use of attenuated $S$. Typhi strains as live-vector vaccines. $S$. Typhi presents multiple advantages as a live-vector, including (a) oral delivery, (b) targeting of $\mathrm{M}$ cells overlying gutassociated lymphoid tissue (inductive sites for immune responses), (c) internalization by DC and macrophages, and (d) stimulation of broad immune responses (127). Indeed, multiple clinical 
Table 1 | Selected licensed $\boldsymbol{S}$. Typhi vaccines and vaccine candidates.

\begin{tabular}{|c|c|c|c|c|c|c|c|c|}
\hline $\begin{array}{l}\text { Type of } \\
\text { vaccine }\end{array}$ & Trade name & Licensed & $\begin{array}{l}\text { Manufacturer/ } \\
\text { developer }\end{array}$ & $\begin{array}{l}\text { Number of } \\
\text { doses }\end{array}$ & $\begin{array}{l}\text { Efficacy } \\
\text { (field trials) }\end{array}$ & $\begin{array}{l}\text { Minimum age for } \\
\text { administration }\end{array}$ & Immunogenicity data & Reference \\
\hline $\begin{array}{l}\text { Inactivated } \\
\text { whole cell }\end{array}$ & $\mathrm{N} / \mathrm{A}$ & Yes & $\begin{array}{l}\text { No longer being } \\
\text { manufactured }\end{array}$ & 2 & 60-80\% & N/A & $\begin{array}{l}\text { Serum antibodies, lymphocyte proliferation, PBMC } \\
\text { migration inhibition }\end{array}$ & (66-68) \\
\hline \multirow[t]{9}{*}{$\begin{array}{l}\text { Live } \\
\text { attenuated }\end{array}$} & Ty21a (Vivotif $®$ ) & Yes & Crucell Switzerland Ltd & $3-4$ & 60-80\% & $\geq 6$ years & $\begin{array}{l}\text { Serum antibodies, ASC, ALS, ADCC, } \\
\text { opsonophagocytosis, B memory, lymphocyte } \\
\text { proliferation, production of multiple cytokines, and } \\
\text { chemokines, CTL activity, cross-reactivity with } S \text {. } \\
\text { Paratyphi A \& B }\end{array}$ & $\begin{array}{l}(52,66,67 \\
78-92)\end{array}$ \\
\hline & CVD 906 & No & CVD-UMB & 1 & $N / A$ & N/A & $\begin{array}{l}\text { Serum antibodies, jejunal IgA, ASC, lymphocyte } \\
\text { proliferation, IFN- } \gamma \text { and IL-6 production }\end{array}$ & $(105-107)$ \\
\hline & CVD 908 & No & CVD-UMB & 1 & N/A & N/A & $\begin{array}{l}\text { IgA ASC, serum IgG, lymphocyte proliferation, } \\
\text { IFN- } \gamma \text { and IL-6 production }\end{array}$ & $(107-109)$ \\
\hline & CVD 906-htrA & No & CVD-UMB & 1 & $N / A$ & N/A & $\begin{array}{l}\text { Serum antibodies, jejunal IgA, ASC, lymphocyte } \\
\text { proliferation }\end{array}$ & $(110)$ \\
\hline & CVD 908-htrA & No & CVD-UMB & 1 & $N / A$ & N/A & $\begin{array}{l}\text { Serum antibodies, jejunal IgA, ASC, lymphocyte } \\
\text { proliferation, IFN- } \gamma \text { production }\end{array}$ & $(110,111)$ \\
\hline & CVD 909 & No & CVD-UMB & 1 & N/A & N/A & $\begin{array}{l}\text { Serum antibodies, ASC, ALS, B memory, } \\
\text { opsonophagocytosis, lymphocyte proliferation, } \\
\text { cross-reactivity against } S \text {. Paratyphi A and B }\end{array}$ & $(89,90,112)$ \\
\hline & Ty800 & No & $\begin{array}{l}\text { Massachusetts General } \\
\text { Hospital }\end{array}$ & 1 & N/A & $\mathrm{N} / \mathrm{A}$ & $\lg A$ ASC, serum $\lg G$ and $\lg A$ & (113) \\
\hline & M01ZH09 & No & Microscience Limited & 1 & N/A & N/A & $\begin{array}{l}\text { Serum antibodies, ASC, ALS, opsonophagocytosis, } \\
\text { bactericidal, lymphocyte proliferation, IFN- } \gamma \\
\text { production }\end{array}$ & $(114-118)$ \\
\hline & x3927 & No & CVD-UMB & 1 & $\mathrm{~N} / \mathrm{A}$ & $\mathrm{N} / \mathrm{A}$ & Serum antibodies, Jejunal slgA, ASC & $(105)$ \\
\hline \multicolumn{9}{|l|}{ SUBUNIT } \\
\hline \multirow{6}{*}{$\begin{array}{l}\text { Vi } \\
\text { polysaccharide }\end{array}$} & Typhim Vi® & Yes & Sanofi Pasteur & 1 & $55-72 \%$ & $\geq 2$ years & Serum antibodies & $(66,67,72)$ \\
\hline & Typherix $®$ & Yes & GlaxoSmithKline & 1 & $61 \%$ & $\geq 2$ years & Serum antibodies & $(66,67,69)$ \\
\hline & Typbar® & Yes & Bharat Biotech & 1 & N/A & $\geq 2$ years & Serum antibodies & (73) \\
\hline & Vax-TyVi® & Yes & Finlay Instituto & 1 & N/A & $\geq 5$ years & Serum antibodies & (74) \\
\hline & TyViVac & Yes & $\begin{array}{l}\text { Dalat Vaccine Company } \\
\text { (DAVAC) }\end{array}$ & 1 & N/A & $\geq 2$ years & Serum antibodies & Product insert \\
\hline & BioTyph ${ }^{\top M}$ & Yes & BioMed & 1 & N/A & $\geq 2$ years & Serum antibodies & Product insert \\
\hline
\end{tabular}




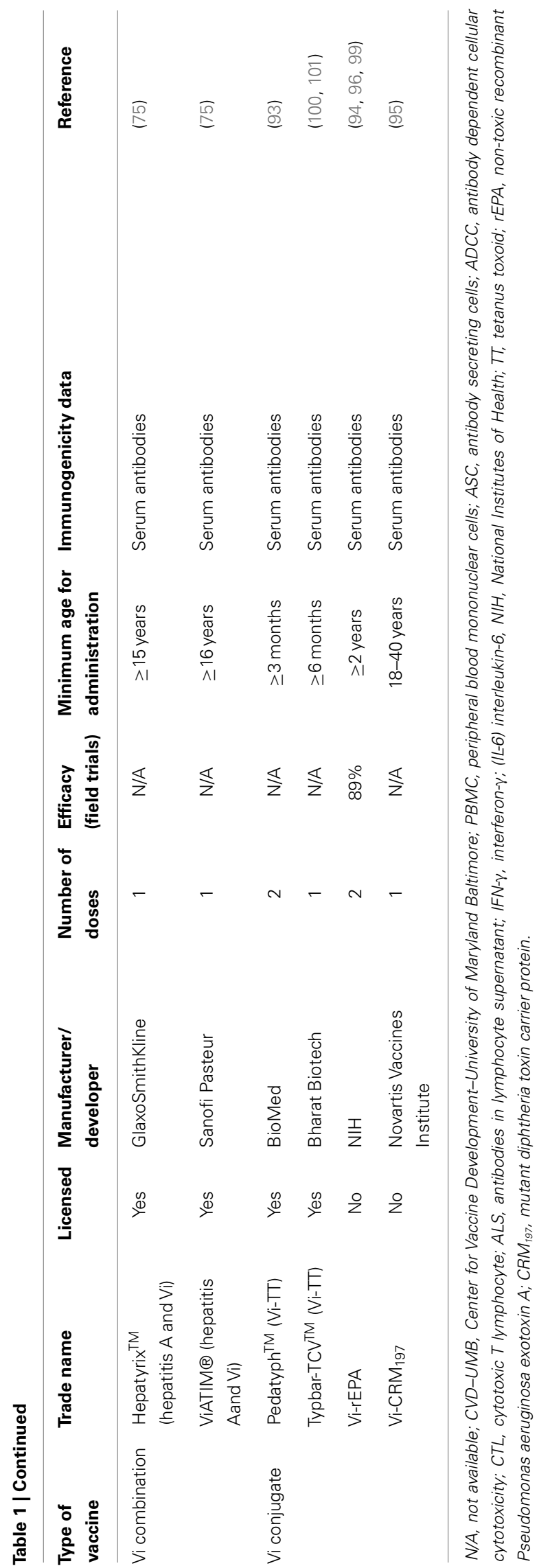

trials have been performed to investigate the immunogenicity of genetically engineered $S$. Typhi expressing foreign antigens (111, 127-134). While these studies have detected only modest immune responses against the foreign antigens, novel engineering strategies hold great potential to enhance the immunogenicity of such vaccines (127). This remains an important avenue of research and improved understanding of immune responses elicited by $S$. Typhi and $S$. Paratyphi A vaccines may facilitate these efforts.

\section{ADAPTIVE RESPONSES TO $S$. Typhi IN VOLUNTEERS IMMUNIZED WITH LICENSED TYPHOID VACCINES AND VACCINE CANDIDATES}

As discussed above, immunity to $S$. Typhi is complex involving antibodies and CMI (135-138). Because $S$. Typhi is a facultative intracellular bacterium, we and others have hypothesized that both antibodies and CMI might play complementary roles in protection from infection. While antibodies are likely to play an important role in defense against extracellular bacteria, CMI is expected to be essential in eliminating $S$. Typhi-infected cells. Based on results from studies using specimens from subjects immunized with attenuated typhoid vaccines, we surmise that serum antibodies, SIgA, $\mathrm{CD}^{+}, \mathrm{CD}^{+}$, and other T-cell subsets (e.g., mucosal associated invariant T-cells, MAIT), as well as the interaction between $\mathrm{T}$, $\mathrm{B}$, and antigen-presenting cells (APC, e.g., macrophages, DC) are all likely to contribute to an effective acquired immune response against typhoid fever (Figure 1). However, the relative contribution of each main arm of the effector immune response, i.e., humoral and cellular, and the antigen specificity of the responses remain largely unknown. Below, we will critically address the key humoral and CMI responses, which we believe are essential in generating "protective" immunity against $S$. Typhi infection, as well as discuss current gaps in knowledge, which need to be addressed to enable the identification of immunological correlates of protection in enteric fevers.

\section{HUMORAL RESPONSES Antibodies}

Numerous studies have reported serum antibody production following $S$. Typhi infection and immunization. Antibodies against the $\mathrm{O}$ antigen of $S$. Typhi LPS, the Vi antigen, and the $\mathrm{H}$ antigen are routinely measured as markers of immunogenicity following S. Typhi immunization $(67,110,112-114,139,140)$. Despite extensive study, the precise role that antibodies play in protection against $S$. Typhi remains unknown. As discussed above, relapses of typhoid fever occur in individuals despite elevated titers of serum anti-S. Typhi antibodies $(34,141)$ and in a recent human challenge with wild-type $S$. Typhi, pre-challenge levels of anti-H and $\mathrm{Vi}$ antibodies did not correlate with protection (63). These studies showed that volunteers who were diagnosed with typhoid demonstrated increases in $\operatorname{IgG}, \operatorname{IgM}$, and IgA to LPS and $\mathrm{H}$ antigens while little change was seen in volunteers who did not succumb to the disease (63). Anti-Vi levels remained unchanged throughout the study (63). Nevertheless, the fact that Vi polysaccharide vaccines can induce protection against typhoid indicates that highanti-Vi antibodies are protective. In fact, defined levels of serum anti-Vi antibodies $(1.4-2.0 \mu \mathrm{g} / \mathrm{ml})$ have been reported to act as a serological surrogate of protection in Vi-rEPA conjugate vaccine 


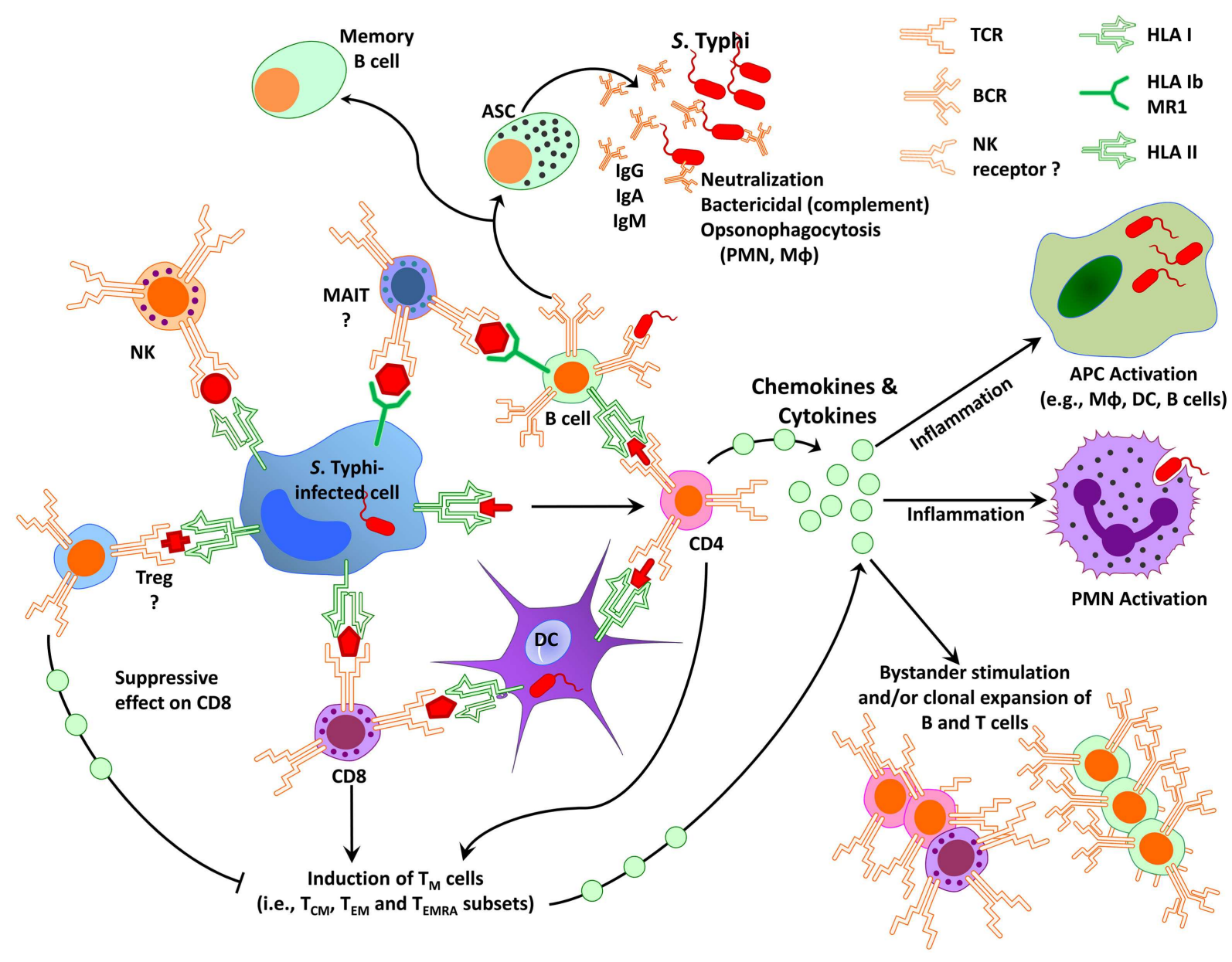

FIGURE 1 | Simplified diagram of immunity to $\boldsymbol{S}$. Typhi in humans Immunity to $S$. Typhi is extremely complex involving multiple antigen-presenting cells (e.g., macrophages, dendritic cells, B cells) and effector cells (e.g., various effector and regulatory T-cell subsets, B cells, NK, and MAIT cells). APC, antigen-presenting cells; ASC, antibody secreting cells; DC, dendritic cells; CD8, CD8 ${ }^{+}$T-cells; CD4, CD4+ T-cells; MAIT, mucosal associated invariant T-cells; $M \varphi$, macrophages; NK, natural killer cells; PMN, polymorphonuclear neutrophil; $T_{M}$, memory $T$-cells; $T_{C M}$, central memory T-cells; $T_{E M}$, effector memory T-cells; $T_{E M R A}$, effector memory expressing CD45RA; $T_{\text {reg, }}$ regulatory T-cells; HLA, human leukocytes antigen; HLA-I, HLA class I; HLA-II, HLA class II; BCR, B cell receptor; TCR, T-cell receptor; MR1, HLA-I non-classical (b) molecule MR1; Ig, immunoglobulin. efficacy trials (94). Presumably, anti-Vi antibodies function by counteracting the evasion of innate immune recognition in the intestinal mucosa and obstruction of bacterial-guided neutrophil chemotaxis, which have been proposed as possible mechanisms by which Vi subverts host immune responses (142, 143). Interestingly, the live-attenuated oral vaccine Ty21a, which lacks the $\mathrm{Vi}$ antigen, results in similar levels of protection as those of the Vi polysaccharide vaccine (12), indicating that multiple adaptive immunological responses can lead to effective protection (Table 1). In field studies of an enteric-coated capsule formulation of Ty21a, seroconversion, as measured by anti-O IgG, correlated with protection $(67,144)$. However, in these same clinical trials the seroconversion rate of IgG O antibodies did not predict the poor efficacy of other vaccine formulations (67). Seroconversion against $S$. Typhi-O antigen has, nevertheless, been used as a marker of immunogenicity following immunization with single-dose live-attenuated vaccine candidates (110, 112-114, 140). In addition to serum antibodies, S. Typhi-specific IgA can be found in saliva, intestinal fluids, and stools following oral immunization with live-attenuated $S$. Typhi or natural infection $(26,78,145,146)$.

Immunoglobulins can be divided into subclasses (e.g., IgA1 and IgA2) based on structural, antigenic, and functional differences (147). The subclasses of IgA are not evenly distributed among bodily fluids with IgA1 dominating in serum and IgA2 found primarily in secretions. In individuals immunized with Ty21a vaccine, $S$. Typhi-specific IgA1 predominated in serum, saliva, and tears, while IgA2 predominated in intestinal lavage fluid (146). IgG can be subclassified into IgG1-4 with different subclasses typically responding to different types of antigen. For example, IgG1 and IgG3 are generally induced by protein antigens, while IgG2 and IgG4 antibodies are associated with polysaccharide antigens (147). Interestingly, however, serum antibodies against Salmonella LPS belong primarily to the IgG1, IgA1, and IgA2 subclasses (148). In contrast, as expected, IgG2 anti-Vi was found to be the predominant IgG subclass in a $\mathrm{Vi}$ polysaccharide vaccine study 
in Nepal (33). Moreover, following a single subcutaneous dose of an S. Typhi vaccine candidate containing porins (protein antigen) IgM and both IgG1 and IgG2 seroconversions were detected (136). Unfortunately, no information is available on the avidity of anti-S. Typhi antibodies elicited by natural infection or immunization. This is a key measurement of the strength of the attachment of antibodies to their antigen, which is highest after B cells have been adequately primed and is an important measurement of the strength of the anamnestic response. Further understanding of the specific immunoglobulin subclasses and avidity associated with protective responses will be of importance in informing decisions regarding vaccine development.

Despite the large amounts of data regarding production of antibodies against $S$. Typhi, there have been few investigations of the functional properties of these antibodies. Early studies indicated that $S$. Typhi-specific IgA was responsible for antibody dependent cellular cytotoxicity (ADCC) following Ty21a immunization (87). In Nepal, an S. Typhi endemic region, bactericidal activity of serum was shown to increase with age; however, no correlation was found between bactericidal titer and anti-Vi titers (33). Recently, we, and others, have reported the induction of functional opsonophagocytic bactericidal $S$. Typhi-specific antibodies that might assist in the elimination of S. Typhi $(90,118)$. These opsonophagocytic antibodies appear to be of the IgG isotype. Further investigation of these functional antibodies may lead to improved measures of immunogenicity and might prove to be more closely associated with protective immunity than antibody measurements by ELISA.

In sum, the sometimes conflicting and fragmentary data regarding the role of antibodies in defense against $S$. Typhi suggest that while they may contribute to an effective response, they are unlikely to represent the dominant mediator of protection in humans following exposure to wild-type organisms.

\section{B cells}

Although, studies in knockout mice indicate that B cells play an important role in protection against $S$. Typhimurium (149), the precise role that $\mathrm{B}$ cells play in protection against $S$. Typhi in humans remains unknown. Antibody production is clearly a major function of B cells; however, B cells also contribute to immune responses via antigen presentation, cytokine production, and the initiation of T-cell responses. For example, Salmonella-specific primary human B cells are able to internalize $S$. Typhimurium via their $B$ cell receptor and stimulate a strong recall response by cytotoxic $\mathrm{CD}^{+}$T-cells (150). In fact, following internalization, Salmonella survive in the B cell and antigens are loaded onto MHC class I for cross-presentation to $\mathrm{CD}^{+}{ }^{+} \mathrm{T}$-cells $(150)$. These results are supported by our previous observations showing that $S$. Typhiinfected B cells can serve as excellent APC for $S$. Typhi antigens. We reported that Epstein-Barr virus (EBV)-transformed lymphoblastoid B cell lines (B-LCL) are able to effectively stimulate CD4 ${ }^{+}$ cells as well as classical and non-classical CD8 ${ }^{+}$cells $(82-85,92$, 121-123, 151, 152). These findings also re-emphasize the importance of communication among immune cell compartments and the possibility that B cells contribute to host defense from $S$. Typhi infection through mechanisms beyond their primary role in antibody production (20) (Figure 1).
Antibody secreting cells. A key aspect of B cells is their ability to undergo cell differentiation and become antibody secreting cells (ASC) (153). In Salmonella infection, specific ASC circulate briefly systemically, peaking at $\sim 7-10$ days after antigen encounter, before homing to mucosal effector sites $(91,110,112,113,115,140$, 144, 154-157). However, prolonged exposure to antigen results in extended circulation of $S$. Typhi-specific ASC in peripheral blood (158). In fact, patients with prolonged diarrhea have circulating ASC throughout the duration of the pathogen exposure (158). Following mucosal antigen encounter (i.e., oral immunization), $S$. Typhi-specific IgA ASC predominate followed by substantial $\operatorname{IgM}$ ASC and low numbers of $\operatorname{IgG}$ ASC $(79,158)$. Of note, the magnitude of ASC response displays considerable inter-individual variation. Three main factors appear to dictate the magnitude of the response: antigen type (live versus killed), number of vaccine doses ingested, and formulation of the vaccine (158). Specifically, immunization with a live oral vaccine resulted in higher magnitude of ASC responses compared to a killed vaccine (159). Ingestion of three doses of vaccine resulted in higher numbers of S. Typhi-specific ASC than did two doses and, although there was no further increase in the peak number of ASC following six doses, the response remained higher for a longer duration (158). Additionally, different vaccine formulations (i.e., gelatin capsules, enteric-coated capsules, suspension) showed different magnitudes of response, with the suspension-formulation, resulting in the highest number of S. Typhi-specific ASC $(79,158)$. Notably, the magnitude of the IgA ASC response against the $\mathrm{O}$ antigen induced by different formulations and schedules of Ty21a correlated with the efficacy shown in field trials of the same formulations and schedules $(79,144)$. Other studies showed that the serum antibody increased concomitantly with increasing ASC numbers, and that, when ASC numbers were low, serum antibody responses were undetectable (79). Consequently, it has been proposed that detection of ASC is a more sensitive measurement of immunogenicity than serum antibody titers. The homing patterns of S. Typhispecific ASC have been rigorously studied and are discussed in detail below.

Memory B cells. It is widely accepted that immunological memory is of critical importance for the development of long-lasting protective responses following immunization (160). Memory B cells $\left(\mathrm{B}_{\mathrm{M}}\right)$ are long-lived antigen primed cells that upon antigenic stimulation during a secondary response undergo rapid terminal differentiation into plasmablasts and plasma cells (161). While there are multiple classification methods to define this heterogeneous population, most $\mathrm{B}_{\mathrm{M}}$ are widely accepted to exhibit the phenotype $\mathrm{CD} 19^{+} \mathrm{CD} 27^{+} \mathrm{IgD}^{+/-}$, although a minor $\mathrm{B}_{\mathrm{M}}$ subset lacking CD27 expression has also been reported (162). Of note, it has been reported that $B_{M}$ are able to mature either inside or outside of the germinal centers and that this phenomenon may be T-cell-dependent or independent $(161,163)$. We have recently made the novel observation that immunization with attenuated $S$. Typhi vaccines elicits $\mathrm{CD} 19^{+} \mathrm{CD} 27^{+} \mathrm{B}_{\mathrm{M}}$ specific for $S$. Typhi antigens (e.g., LPS, flagella, Vi) (89) and described the longevity (up to 1 year), magnitude, and characteristics of these responses (89). Notably, strong $B_{M}$ responses against both T-cell-dependent (flagella) and T-cell-independent (LPS and Vi) antigens were 
identified in volunteers primed with CVD 909 (a Vi expressing liveattenuated $S$. Typhi vaccine candidate). These results suggest that immunization with CVD 909 was capable of mucosally priming the immune system to deliver robust and sustained Vi-specific $B_{M}$ responses to a subsequent parenteral exposure. LPS-specific $B_{M}$ responses were also observed in volunteers primed with CVD 909, but these responses were of lower magnitude than those against Vi. Similar to findings for ASC, LPS-specific IgA $B_{M}$ cells predominated over LPS-specific IgG $B_{M}$ responses. In the same study, we observed that volunteers immunized with Ty21a also developed IgA $B_{M}$ responses to LPS, but only a single volunteer developed IgG $B_{M}$ responses against LPS. Moreover, both CVD 909 and Ty21a were capable of inducing anti-S. Typhi flagella IgG and IgA $B_{M}$ responses. Finally, we observed a strong association between the frequency of antigen-specific $\mathrm{B}_{\mathrm{M}}$ cells and antibody levels, supporting an important role of this cell population in the generation of humoral responses. Recent studies have shown that $S$. Typhi porins can induce short- and long-lasting IgG and IgM responses in humans, a response likely to be mediated by $B_{M}$ (136). Interestingly, studies in mice have also identified IgM $B_{M}$, which are likely to secure long-term production of bactericidal IgM antibodies following inoculation with $S$. Typhi porins (164). This study also reported the induction of Type $1 \mathrm{~T}$ follicular helper (Tfh) cells that produce IFN- $\gamma$, which are thought to support the generation of these $B_{M}$ (164). However, the relative contribution of the various $B_{M}$ and Tfh subsets to enduring protection remains to be determined. Further characterization of these responses and cell subsets may help elucidate mechanisms of sustained protection against $S$. Typhi.

B cell phosphorylation. Early signaling events that occur following encounter of B cells with S. Typhi and other pathogens are of critical importance in the generation of cellular responses. Recently, we described the phosphorylation patterns associated with $S$. Typhi-specific B cells (165). We reported that exposure of PBMC from healthy volunteers to fluorescently labeled, heat-killed $S$. Typhi resulted in bacterial binding to naïve and unswitched memory (Um) B cells as detected by flow cytometry. Although naive B cells that interacted with $S$. Typhi were observed, phosphorylation of Stk, Akt, and p38MAPK were not identified in this subset. In contrast, Um B cells showed multi-phosphorylation of all three proteins assayed, as well as cells that phosphorylated only p38MAPK or Akt and p38MAPK. Interestingly, different antigenic structures appeared to induce different patterns of phosphorylation. For example, the phosphorylation patterns induced by $S$. Typhi were dramatically different from the phosphorylation patterns induced by the Gram-positive bacterium Streptococcus pneumoniae. These novel studies provide the first glimpse of the activation pathways of $S$. Typhi-specific B cell responses in humans. Further characterization of these mechanisms can provide key information to help advance the generation of novel vaccine strategies.

B cell homing. Although most of our knowledge of immune responses against Salmonella in humans is derived from studies using peripheral blood, effector immunity in the local microenvironment of the gut is likely to be of paramount importance in the understanding of protection against $S$. Typhi infection. Mucosal derived circulating IgA ASC detected after administration of live oral typhoid vaccines have been used to estimate the degree of priming of the local intestinal immune system (137). These cells are believed to home to the lamina propria of the intestinal mucosa where they will synthesize and release antibodies (166). Selective homing of cells (including plasmablasts) to the small intestine is believed to be largely driven by the expression of integrin $\alpha_{4} \beta_{7}$ and chemokine (C-C motif) receptor (CCR)9 (167), while CCR10 expression appears to be involved in homing to "common" mucosal tissues (168). The primary site of antigen encounter has been shown to affect the expression of homing receptors on ASC (169). Following mucosal antigen delivery by Ty21a administration, robust migration of $S$. Typhi-specific IgM and IgA ASC toward chemokine (C-C motif) ligand (CCL) 25 and CCL28, the ligands for CCR9 and CCR10, respectively, were noted (170). In contrast, systemically derived tetanus-specific ASC did not migrate toward either CCL25 or CCL28, supporting the mucosal specificity of these ligands. Previous work has shown that after oral antigen administration, the majority of ASC produce the mucosal Ig-isotype, IgA, and all of them express the gut homing receptor, integrin $\alpha_{4} \beta_{7}$, thus, implying mucosal homing of these cells $(137,154,157,158)$. Moreover, when comparing oral Ty21a and parenteral Vi-conjugate vaccines, Ty21a but not Vi immunization recapitulates the homing receptor profile of ASC occurring in natural infection (e.g., integrin $\alpha_{4} \beta_{7}$ expression) (155). We have recently shown that sorted IgG and IgA ASC recognizing S. Typhi-LPS are predominantly CD19 ${ }^{+} \mathrm{CD} 27^{+}$(a phenotype associated with $\mathrm{B}_{\mathrm{M}}$ and plasmablasts) with selective gut homing potential (e.g., integrin $\alpha_{4} \beta_{7}{ }^{+} \mathrm{CD} 6 \mathrm{~L}^{-}$) (91). Of note, however, both IgG and IgA cells were also observed among integrin $\alpha_{4} \beta_{7}{ }^{+}$ $\mathrm{CD} 2 \mathrm{~L}^{+}$, suggesting that they have the capacity to home to the gut, as well as peripheral lymph nodes, and perhaps other secondary lymphoid tissues. Further studies of the homing potential of $S$. Typhi-specific $B_{M}$ and plasmablasts is of critical importance to further our understanding of the mechanisms underlying the induction of antigen-specific cells which have the ability to home to the gut (the initial site of infection), as well as to other lymphoid tissues where $S$. Typhi resides following systemic dissemination.

\section{CELL MEDIATED IMMUNE RESPONSES}

As for other intracellular infections, CMI responses against $S$. Typhi infection rely largely on two types of cells: $\mathrm{CD} 4^{+}$and $\mathrm{CD} 8^{+}$ T-cells $(51,81,138,171)$. The presence of both $\mathrm{CD}^{+}$helper Tcells and classical class Ia and non-classical HLA-E-restricted $S$. Typhi-specific $\mathrm{CD} 8^{+}$T-cells have been observed in individuals with typhoid fever or immunized with Ty21a and other attenuated leading typhoid vaccine candidates, including CVD 908-htrA and CVD 909 (51, 82-85, 88, 92, 114, 122, 123, 152, 172). A succinct description of these responses follows.

\section{T-cell responses}

We, and others, have reported that $S$. Typhi can stimulate the production of an array of pro-inflammatory cytokines including IFN- $\gamma$ by specific $\mathrm{CD}^{+}$and $\mathrm{CD} 8^{+}$T-cells following immunization $(52,84,85,88,107,114,121)$. For example, IFN- $\gamma$ production by $\mathrm{CD}^{+}$and $\mathrm{CD}^{+}{ }^{+} \mathrm{T}$-cells in response to $S$. Typhi LPS and flagella 
antigens has been shown up to 56 days after immunization with attenuated $S$. Typhi vaccines $(84,107,121)$. Similarly, in subjects immunized with Ty21a, it has been shown that $S$. Typhi GroEL triggers IFN- $\gamma$ production by $\mathrm{CD} 8^{+}$cells $(85)$. In addition, $S$. Typhi immunization elicits the generation of cytotoxic $\mathrm{CD} 8^{+}$T-cells $(84,121,122)$. Cytotoxic CD8 ${ }^{+}$T-cells induce apoptosis within minutes of contact with their target by at least two lytic mechanisms (173-175). One, based on granular exocytosis involving perforin and granzymes (176), and another involving a molecule called FAS or APO-1 (177). Using PBMC from individuals immunized with the Ty21a typhoid vaccine (85) and the vaccine candidate strain CVD 909 (123), we have shown that the killing of $S$. Typhi-infected targets by specific $\mathrm{CD}^{+}$T-cells is largely through a FAS-independent, granule-dependent pathway. These findings were confirmed using two types of autologous target cells: phytohemagglutinin (PHA)-stimulated PBMC, as well as B-LCL $(85,123)$. Interestingly, killing of these targets involved antigenic presentation by both classical class Ia and non-classical HLA-E molecules indicating that multiple mechanisms might be involved in killing of S. Typhi-infected cells $(84,85,121)$.

Cell mediated immunity against $S$. Typhi mediated by $\mathrm{CD} 4^{+}$ and $\mathrm{CD}^{+}{ }^{+} \mathrm{T}$-cells appears to depend on the nature of the stimulant. $\mathrm{CD}^{+}$cells were more prone to respond to $S$. Typhi soluble antigens while $\mathrm{CD}^{+}$cells were more likely to be activated by $S$. Typhi-infected targets $(84,121,138,152)$. These results emphasize the importance of selecting the appropriate type of stimulant when designing experiments aimed at evaluating T-cell responses. Another important issue related to the host's response to S. Typhi is the dichotomy between T-cell and humoral responses observed in individual subjects. In the past, our group and others have tried exhaustively, and failed, to observe a correlation on a volunteer by volunteer basis between serum antibody titers to $S$. Typhi LPS and/or S. Typhi flagella and CMI in individuals immunized with various attenuated $S$. Typhi vaccine strains $(42,107,121,140)$. These observations support the contention that the development and dominance of humoral and/or CMI responses in individual volunteers is likely multifactorial and influenced by individual host factors (e.g., genetic makeup, gut microbiome composition).

On the basis of the expression of defined surface molecules, T-cells can be simplistically subdivided into two main subsets: naïve and memory $\mathrm{T}\left(\mathrm{T}_{\mathrm{M}}\right)$ cells. Induction of strong and persistent memory T-cell responses is one of the hallmarks of successful vaccination $(160,171)$. Although $\mathrm{T}_{\mathrm{M}}$ can be divided into a multitude of subsets, it is widely accepted that the main $\mathrm{T}_{M}$ subsets are central memory $\mathrm{T}$-cells $\left(\mathrm{T}_{\mathrm{CM}}\right)$, and effector memory $\mathrm{T}$-cells $\left(\mathrm{T}_{\mathrm{EM}}\right)(178,179) . \mathrm{T}_{\mathrm{CM}}$ express surface molecules for memory (e.g., CD45RO), as well as the chemokine receptor CCR7 and CD62L (L-selectin) molecules, which allow efficient homing to peripheral lymph nodes $(178,179)$. $\mathrm{T}_{\mathrm{EM}}$ also express CD45RO, but down-regulate the expression of CCR7 and CD62L, which allows them to circulate and migrate to the spleen and non-lymphoid tissues. In humans, some $\mathrm{CD} 8^{+} \mathrm{T}_{\mathrm{EM}}$ lack the expression of CD45RO and express CD45RA, a molecule present on naïve T-cells. This subset is termed $\mathrm{T}_{\mathrm{EMRA}}$ or "terminal memory" cells $(178,179)$. Recently, we provided the first demonstration of the induction and longevity (up to 2 years) of $\mathrm{T}_{\mathrm{CM}}, \mathrm{T}_{\mathrm{EM}}$, and $\mathrm{T}_{\mathrm{EMRA}}$ multifunctional HLA-E restricted CD8 ${ }^{+}$
$\mathrm{T}_{\mathrm{M}}$ cells after Ty21a immunization, suggesting that these cells are important in long-term immunity to $S$. Typhi (82). In these experiments, we showed that following Ty21a vaccination, multiple pro-inflammatory cytokines/chemokines (including IFN- $\gamma$ ) are produced by $\mathrm{CD} 8^{+}$T-cells in response to stimulation with $S$. Typhi-infected targets, and that these responses are multiphasic in nature (82). We also observed a striking correlation among subjects who showed strong $\mathrm{CD} 8^{+} \mathrm{T}_{\mathrm{CM}}$ subsets and produced IL-2 and IFN- $\gamma$ at early times and the presence of long-term immune responses (82). We speculated that this phenomenon might be due to the fact that IL- 2 and/or IFN- $\gamma$-secreting $\mathrm{CD} 8^{+} \mathrm{T}_{\mathrm{CM}}$ subsets at early times after vaccination result in the development of a larger pool of long-lived specific $\mathrm{CD}^{+} \mathrm{T}_{\mathrm{M}}$ cell subsets (e.g., $\mathrm{CD} 8^{+}$ $\mathrm{T}_{\mathrm{CM}}, \mathrm{T}_{\mathrm{EM}}$ and $\mathrm{T}_{\mathrm{EMRA}}$ subsets), which could lead to improved control against re-infection. Recently, these results were confirmed and extended using multichromatic flow cytometry to measure six cytokines simultaneously (IL-10, IL17A, IL-2, IFN- $\gamma$, TNF- $\alpha$, and MIP-1 $\beta$ ) (92). In this work, our group demonstrated, for the first time, the presence of IL-17A-producing CD8 ${ }^{+}$cells in Ty21a vaccinees (92). These findings are of great significance since consensus is emerging that multifunctional $\mathrm{CD} 4^{+}$and $\mathrm{CD} 8^{+}$T-cells are important in determining the effectiveness of immunity to either vaccination (180) or exposure to intracellular microorganisms in humans, including HIV $(181,182)$ and Mycobacterium tuberculosis $(183,184)$.

It is important to highlight that the balance between suppressive and pro-inflammatory responses might be of critical importance in the host's ability to mount effective immune responses. For example, experiments in mice have shown that the equilibrium between suppressive $\mathrm{T}_{\text {reg }}$ and pro-inflammatory $\mathrm{T}_{\text {eff }}$ responses influence the clearance or persistence of S. Typhimurium (185). $\mathrm{T}_{\text {reg }}$ are characterized by the expression of high levels of the IL-2 receptor (CD25) and transcription factor Forkhead box P3 (FoxP3). Activated $\mathrm{T}_{\text {reg }}$ may traffic to the sites of specific immune responses and exert their regulatory functions via cell-cell interactions [i.e., cytotoxic T lymphocyte antigen-4 (CTLA-4) competition for co-stimulatory molecules (CD80 and CD86) on APC], consumption of IL-2, and production of anti-inflammatory factors [i.e., IL-10 and transforming growth factor (TGF)- $\beta$ ] (186). Observations in humans, including IL-10 production by PBMC from volunteers immunized with Ty21a and CVD909 in response to $S$. Typhi flagellar antigen $(52,123)$ and IL-10 detection in the sera of individuals during S. Paratyphi A infection (6) indicate a potential role for $\mathrm{T}_{\text {reg }}$ in establishing a balanced immune response against $S$. Typhi and $S$. Paratyphi infections. Despite these intriguing observations, the role of $\mathrm{T}_{\text {reg }}$ following $S$. Typhi or $S$. Paratyphi infection or immunization in humans remains unknown.

\section{Background T-cell responses and their possible role in controlling Salmonella infection}

A common finding when measuring T-cell immune responses in humans vaccinated against enteric bacteria, such as $S$. Typhi, is the presence of background $S$. Typhi-specific responses among individuals prior to immunization, even in the absence of travel to endemic areas $(81,82,84,92,121,123,136,152)$. These background responses are characterized by the presence of specific 
immune responses against antigens from enteric bacteria in individuals with no history of immunization against, or infection with, the enteric pathogen. Although this background is rather variable, with higher levels observed in individuals in regions with limited sanitation systems (unpublished observations), this phenomenon has been observed in subjects across the World. A prevailing hypothesis is that these background responses are due to the presence of cross-reactive T-cells acquired during previous infections by other enteric pathogens $(81,136,151)$ or reacting to the normal gut microbiota (187-190). Although it is difficult to contest these possibilities, it is reasonable to hypothesize that defined subset(s) of T-cells such as innate-like T-cells, including TCR $\gamma \delta$ T-cells, NK-T-cells, and MAIT, are responsible, at least in part, for the observed background responses (151). For example, TCR $\gamma \delta$ T-cells and NK-T-cells from healthy volunteers with serum antibodies against non-typhoidal Salmonella have been reported to produce higher amounts of IFN- $\gamma$ as compared to conventional $\mathrm{CD}^{+}{ }^{+}$and $\mathrm{CD}^{+}{ }^{+}$T-cells in response to stimulation with Salmonella antigens (191). It is also known that MAIT cells play an important physiological role in host bacterial defense and may also be involved in inflammatory disorders, particularly at mucosal surfaces (192-194). Previous work has demonstrated that MAIT cells may play a significant role in M. tuberculosis and HIV infections in humans. Gold and colleagues have shown in humans that MAIT cells are decreased in the blood of patients with active TB infection. Other reports have shown that the levels of MAIT cells were severely reduced in circulation in patients with HIV-1 infection $(195,196)$. Their decline was associated with the time of diagnosis (196) and may reflect diverse mechanisms including their accumulation in tissues and activation and functional exhaustion $(195,196)$. Of note, a recent study from our group has shown that MAIT cells can be activated by B cells infected with various bacteria (commensals and pathogens from the Enterobacteriaceae family, including $S$. Typhi), but not by uninfected cells (151). These responses were restricted by the non-classical MHC-related molecule 1 (MR1) and involved the endocytic pathway. Moreover, the quality of these responses (i.e., cytokine profiles) were dependent on bacterial load but not on the level of expression of MR1 or bacterial antigen on B cell surface (151). Based on these studies, it is reasonable to speculate that baseline responses by functionally active innate-like T-cells (e.g., TCR $\gamma \delta$ T, NK-T, MAIT) and/or those elicited early upon microbial stimulation by vaccination or acute infection, might contribute to prevent $S$. Typhi infection. These cell subsets may be responsible for controlling the infection soon after exposure (subclinical infection), and contributing to clear the infection without causing overt disease once the specific adaptive immune responses are fully developed.

\section{Dendritic cell cross-presentation and CD8 ${ }^{+}$T-cells}

The mechanism(s) underlying $S$. Typhi regulation of the development of specific T-cell responses in humans remains unclear. Studies in mice have shown that DC can either directly (upon uptake and processing of Salmonella) or indirectly (by bystander mechanisms) elicit Salmonella-specific CD8 ${ }^{+}$T-cells (197). DC are APC that have a strategic function in the initiation and modulation of the immune responses (198). In addition to presenting exogenous antigens using the conventional MHC class II activation pathway typically used by $\mathrm{CD} 4^{+} \mathrm{T}$-cells, these cells have developed an alternative pathway where exogenous antigens can be presented through an MHC class I activation pathway to CD8 ${ }^{+}$T-cells (198). This alternative pathway is called the cross-presentation pathway (199). Although multiple APC are able to cross-present antigens, DC are the most efficient in vivo (200). Therefore, the successful generation of strong $\mathrm{CD}^{+}$T-cell responses to vaccine antigens might be linked to the modulation of the DC cross-presentation.

Our group has provided the first direct demonstration in humans that DC, through suicide cross-presentation, uptake $S$. Typhi-infected human cells and release IFN- $\gamma$ and IL-12p70, leading to the subsequent presentation of bacterial antigens and triggering the induction of mostly $\mathrm{CD}^{+} \mathrm{CD}^{+} \mathrm{CD}^{+} 5 \mathrm{RA}^{-} \mathrm{CD}^{-} 2 \mathrm{~L}^{-}$ $\mathrm{T}_{\mathrm{M}}$ cells (201). We observed that upon infection with live $S$. Typhi, human DC produced high levels of the pro-inflammatory cytokines IL-6, IL-8, and TNF- $\alpha$ but low levels of IL-12 p70 and IFN- $\gamma$ (201). In contrast, DC co-cultured with S. Typhiinfected cells produced high levels of IL-12 p70, IFN- $\gamma$, and TNF- $\alpha$ (201). These interesting and novel findings are in agreement with previous work showing that IL-12 and IFN- $\gamma$ are essential for resistance to Salmonella infection in mice (21, 202, 203), and that they are likely to also be important in humans $(38,56)$. Thus, it is reasonable to speculate that crosspresentation of vaccine antigens to $\mathrm{CD}^{+}{ }^{+} \mathrm{T}$-cells might be an important mechanism of antigen presentation leading to the generation of protective immune responses against $S$. Typhi infection.

\section{T-cell homing}

Migration or "homing" is a multi-step process where the adhesion of lymphocyte surface homing receptors to their counterparts, addresins, on endothelial cells is the key step (204). As with B cells, the selective homing of effector memory cells to the lamina propria of the small intestine is driven, to a large extent, by the expression of integrin $\alpha_{4} \beta_{7}$ and CCR9 (205-209). For example, virtually all T-cells in the small intestine express CCR9 (206). Another molecule implicated in this process is integrin $\alpha \mathrm{E} \beta 7$ (CD103), which is present in a subset of CCR9 ${ }^{+}$T-cells (210).

Generation of specific memory $\mathrm{CD}^{+}{ }^{+}$and $\mathrm{CD} 8^{+}$T-cells with gut homing potential following oral typhoid immunization has been well described $(81,83,152)$. Previous work has shown that sorted integrin $\beta 7$-expressing memory T-cells (CD45RA $^{-}$ $\beta 7^{\text {high }}$ cells) from volunteers immunized with $S$. Typhi vaccine strain Ty21a when stimulated in vitro produced around 10-fold more IFN- $\gamma$ than the remaining populations $\left(\mathrm{CD}_{4} \mathrm{RA}^{-} \beta 7^{-}\right.$or $\mathrm{CD} 5 \mathrm{RA}^{-} \beta 7^{\text {intermediate }}$ ) (81). Also, using cells from volunteers immunized with the candidate $S$. Typhi vaccine strain CVD 909, our group further characterized the gut homing potential and induction of IFN- $\gamma$ production in the central $\left(\mathrm{T}_{\mathrm{CM}}, \mathrm{CD} 45 \mathrm{RO}^{+}\right.$ $\left.\mathrm{CD} 2 \mathrm{~L}^{+}\right)$and effector $\left(\mathrm{T}_{\mathrm{EM}}, \mathrm{CD} 45 \mathrm{RO}^{+} \mathrm{CD} \mathrm{L}^{-}\right)$memory $\mathrm{T}$ populations (152). Interestingly, we observed that the homing potential of $\mathrm{CD}^{+}$and $\mathrm{CD} 8{ }^{+} \mathrm{T}_{\mathrm{M}}$ subsets were distinct. Although both $\mathrm{CD} 4^{+} \mathrm{T}_{\mathrm{EM}}$ and $\mathrm{T}_{\mathrm{CM}}$ populations produced IFN- $\gamma, \mathrm{CD} 4^{+}$ $\mathrm{T}_{\mathrm{CM}}$ cells were predominantly integrin $\alpha_{4} \beta_{7}{ }^{+}$while CD $4^{+} \mathrm{T}_{\mathrm{EM}}$ were found to include both integrin $\alpha 4 \beta 7^{+}$and integrin $\alpha 4 \beta 7^{-}$ cells. In contrast, IFN- $\gamma$-producing $\mathrm{CD}^{+}$cells were predominantly classical $\mathrm{T}_{\mathrm{EM}}$ and CD45RA ${ }^{+} \mathrm{T}_{\mathrm{EM}}$ ( $\mathrm{T}_{\mathrm{EMRA}}$; CD45RO ${ }^{-}$ 
$\left.\mathrm{CD} 2 \mathrm{~L}^{-}\right)$subsets. Interestingly, while $\mathrm{CD} 8^{+} \mathrm{T}_{\mathrm{EM}}$ included both integrin $\alpha 4 \beta 7^{+}$and integrin $\alpha 4 \beta 7^{-}$cells, $\mathrm{CD} 8^{+} \mathrm{T}_{\mathrm{EMRA}}$ were predominantly integrin $\alpha_{4} \beta_{7}{ }^{+}$(152). By using PBMC from healthy adults immunized with the Ty21a vaccine, we have also reported that $S$. Typhi-specific $\mathrm{CD}^{+}$T-cells are able to co-express high levels of integrin $\alpha_{4} \beta_{7}$, intermediate levels of CCR9 and low levels of CD103 (83). Furthermore, we showed that these specific memory $\mathrm{CD}^{+}{ }^{+} \mathrm{T}$-cells with gut homing potential bear multiple TCR $\mathrm{V} \beta$ specificities (e.g., V $\beta 2,3,8,14$, and 17) (83). Of note, cells used in this study were collected 5-40 months after oral immunization. Thus, $S$. Typhi-specific $\mathrm{CD}^{+} \mathrm{T}_{\mathrm{EM}}$ cells with gut homing potential might persist in circulation over long periods of time. However, because the study used cells isolated exclusively from peripheral blood, we have to consider the possibility that these observations might not reflect the full spectrum of TCR V $\beta$ usage by $S$. Typhi-specific $\mathrm{CD}^{+}$T-cells in the gut microenvironment in vivo. Based on these findings regarding the homing potential of $S$. Typhi-specific cells, it is reasonable to speculate that the observed multiphasic kinetics of the T-cell responses described above might represent decreases in circulating $S$. Typhi-specific T-cells as they home to the gut and other lymphoid tissues, as well as increases due to the release into the circulation of new waves of specific cells generated in lymphoid organs.

\section{MICROBIOTA, CO-INFECTIONS, AND THE HOST IMMUNE RESPONSE FOLLOWING IMMUNIZATION WITH ORAL ATTENUATED TYPHOID AND OTHER ENTERIC VACCINES}

There is growing evidence from clinical studies indicating that the gut microbiota has a profound impact in modulating human immune responses in health and disease, including a significant role in influencing vaccine efficacy $(190,211-213)$. For example, in a study evaluating the oral attenuated $V$. cholerae $\mathrm{O} 1$ vaccine CVD 103-HgR, Lagos and colleagues demonstrated that excessive bacterial growth ("tropical enteropathy") in the small intestine of children in less developed countries might contribute to the low-antibody response to the vaccine (214). In this study, an inverse association was found between bacterial over growth and seroconversion as determined by vibriocidal titers. Reduced vaccine efficacy and immunogenicity in developing countries when compared with North Americans also has been reported with other vaccines, including oral polio and rotavirus $(137,213$, 215). Helminth infections have also been demonstrated to impact vaccine immunogenicity and, for example, anti-helminthic therapy prior to immunization was shown to improve the immune response to the CVD 103-HgR cholera vaccine (216). Regarding $S$. Typhi, recent evidence showed that the induction of $S$. Typhi-specific IgG LPS antibodies following immunization was significantly higher among CVD 908-htrA vaccines infected with Helicobacter pylori than in uninfected subjects. These results are likely the consequence of gastric acid hyposecretion due to $H$. pylori infection which facilitated the passage of CVD 908-htrA through the stomach (217). These observations are supported by reports indicating that the risk of developing typhoid fever is higher in $H$. pylori-infected individuals in underdeveloped countries (218), suggesting that the success of the Ty21a typhoid vaccine in endemic regions might be the result, at least in part, of the high prevalence of $H$. pylori infection accompanied by hypochlorhydria
$(217,219)$. Additionally, evidence in animal models suggests that modulation of the gut microbiota (e.g., with antibiotics, prebiotics, and probiotics) can enhance vaccine efficacy $(220,221)$.

We recently initiated studies to directly investigate the interactions between the microbiome and vaccination with attenuated oral vaccines. We observed that, although Ty21a is a live-attenuated $S$. Typhi vaccine delivered via the oral route, there was no disruption in the composition, diversity, or stability of the fecal microbiota in healthy adult volunteers who received this vaccine (172). However, categorical analysis based on multiphasic CMI responses versus late CMI responses identified a subset of bacterial operational taxonomic units (OTUs) differentiating individuals capable of mounting distinct immunological responses. Generally, individuals who exhibited a multiphasic CMI response to vaccination harbored greater community richness and diversity compared to individuals with only a late CMI response to Ty21a. No differences were identified in community richness or diversity among volunteers characterized as responders or non-responders based on seroconversion ( $S$. Typhi LPS). Although the number of volunteers analyzed was small, this study provides additional information supporting the potential influence of the gut microbiota on the immune response elicited by oral immunization, and perhaps, in protection. Additional studies involving larger numbers of volunteers and a multiplicity of vaccines administered via the oral route are necessary to extend our understanding of the complex role of the gut microbiota in modulating host immunity and vaccination in humans, and its possible role in vaccine efficacy.

\section{CROSS-REACTIVE IMMUNE RESPONSES AMONG $S$. Typhi, $S$.} Paratyphi A, AND S. Paratyphi B

As discussed above, limited information is available regarding host immune responses to $S$. Paratyphi A and S. Paratyphi B in humans. In fact, most of the immune responses believed to be elicited by $S$. Paratyphi A have been inferred from $S$. Typhi studies. Interestingly, field trials of Ty21a have shown modest cross-protection against $S$. Paratyphi B (3), suggesting that cross-reactive immune responses might be responsible. The presence of cross-reactive responses were first reported in the 1980s by Tagliabue et al. who reported the induction of IgA antibodies following oral immunization with Ty21a, which mediate T-cell-dependent ADCC against S. Typhi, $S$. Paratyphi A, and S. Paratyphi B, but not against $S$. Paratyphi C (87). We have recently identified cross-reactive immunological responses against $S$. Paratyphi A and $S$. Paratyphi B in subjects orally immunized with Ty21a (91). IgA ASC that recognized LPS from $S$. Paratyphi A and $S$. Paratyphi B were observed, but at a lower magnitude than responses against $S$. Typhi LPS (91). These cross-reactive anti-LPS CD $19^{+} \mathrm{CD} 27^{+}$IgG and IgA ASC displayed the same homing pattern (i.e., a dominant integrin $\alpha_{4} \beta_{7}{ }^{+} \mathrm{CD} 62 \mathrm{~L}^{-}$ subset and a significant proportion of integrin $\alpha_{4} \beta_{7}{ }^{+} \mathrm{CD} 2 \mathrm{~L}^{+}$ cells) as $S$. Typhi-specific ASC. We also reported the induction of antibodies and $\mathrm{B}_{\mathrm{M}}$ to $S$. Typhi LPS and OMP antigens, which crossreact with $S$. Paratyphi A and $S$. Paratyphi B. However, IgA $B_{M}$ reactive to $S$. Typhi was of higher magnitude than those against $S$. Paratyphi $A$ and $S$. Paratyphi B. In contrast, $B_{M}$ to outer membrane proteins (OMP) from $S$. Paratyphi B were similar to those observed for $S$. Typhi-OMP, but higher than those for S. Paratyphi A OMP. In 
a subsequent study, we reported in Ty21a and CVD 909 vaccines the presence of cross-reactive serum antibodies able to mediate opsonophagocytosis of S. Paratyphi A and S. Paratyphi B, albeit at lower levels than those against $S$. Typhi $(90,91)$. Similar observations regarding cross-reactive ASC responses among S. Typhi and $S$. Paratyphi serovars $\mathrm{A}, \mathrm{B}$, and $\mathrm{C}$ were recently reported in Ty21a vaccinees and patients with enteric fevers (222). These crossreactive responses are likely the result of the immunity elicited by $\mathrm{O}: 12$, the trisaccharide (mannose-rhamnose-galactose) repeating unit that comprises the LPS backbone, which is common to $S$. Typhi, S. Paratyphi A, and S. Paratyphi B. Of note, a recent study showed that, although $S$. Paratyphi A and $S$. Paratyphi B do not possess the $\mathrm{Vi}$ antigen, cross-reactive ASC were identified in recipients of the Vi polysaccharide vaccine (223). The authors concluded that this low level of cross-reactivity is likely attributable to $S$. Typhi-LPS contamination of the Vi polysaccharide vaccine. Similar observations were reported by others $(89,139)$. Of note, although to our knowledge there are no reports documenting cross-protection against non-typhoidal Salmonella in Ty21a or Vi vaccinees, these typhoid immunizations elicit cross-reactive ASC against non-typhoidal Salmonella, including S. Typhimurium and Enteriditis that share either O:9, O:12, or both antigens with $S$. Typhi $(224,225)$. In spite of these studies, the precise immune mechanism(s) of the cross-protection observed against $S$. Paratyphi B in Ty21a vaccinees in field trials remains unclear. However, it is tempting to speculate that CMI responses might play a key role in cross-protection. Further studies assessing the basis for these cross-reactive responses, as well as whether immunization with novel attenuated $S$. Paratyphi A vaccines, or wild-type $S$. Paratyphi A infection, results in cross-reactive humoral and CMI responses with S. Typhi and S. Paratyphi B will provide critical information to advance the development of broad-spectrum vaccines to protect against enteric fevers.

\section{"OMICS" STUDIES}

Recent advances in microarray and proteomics technologies have allowed for detection of immunogenic S. Typhi antigens (226, 227). Both immunoaffinity proteomics-based technology and protein microarrays have been utilized to identify key antigens that may be suitable for vaccine development and diagnostics $(226,227)$. Furthermore, transcriptional profiling in peripheral blood of patients infected with $S$. Typhi identified a distinct and reproducible signature that changed during treatment and convalescence (228). Additionally, studies performed in mice and humans have also identified immune signatures common to murine and human systemic salmonellosis (229). Although very few manuscripts have reported the use of these state-of-the-art approaches, these comprehensive analyses of the transcriptional and proteomic profiles provide a foundation for more directed analyses that may have a direct impact on the development of novel vaccines and diagnostics in coming years.

\section{CONCLUDING REMARKS}

Despite decades of effort, the mechanisms of protective immunity in natural infection and vaccination remain largely undefined and many questions remain (Box 1). The vast majority of the information currently available using modern immunological techniques has been obtained using specimens from subjects immunized with attenuated typhoid vaccines. Old challenge studies lacked the appropriate tools to monitor immune cells (e.g., Band T-cells) and in general, have been limited to measurements of serum antibody titers and, in some cases, the use of inadequate CMI methodology available at that time. The "Renaissance" of challenge studies with wild-type $S$. Typhi, such as those being performed in Oxford, is at hand and novel technologies to analyze in unprecedented depth the host immune responses have recently become available. One of these technologies is mass cytometry, also known as Cytometry by Time Of Flight (CyTOF), capable of resolving more than 35 measurements per cells using rare metalconjugated monoclonal antibodies with minimal signal overlap (230-232); a problem that severely limits the number of parameters, which can be evaluated by conventional flow cytometry. This novel technology will enable the simultaneous measurement of the phenotype and function of multiple immune cell types by simultaneously monitoring the cross-talk between traditional players (e.g., B- and T-cells), and new potential players (e.g., innate-like T-cells, including TCR $\gamma \delta$ T-cells, NK-T-cells, and MAIT cells, as well as $\mathrm{T}_{\text {reg }}$ cells) and the possible mechanisms leading to protection against infection. In fact, it is likely that it is the balance (i.e., homeostasis) between effector and regulatory responses that holds the key to understanding protective immunity. Mass cytometry, in conjunction with traditional immunological assays and state-ofthe-art genomics, transcriptomics, proteomics, and metabolomics approaches and the availability of human challenge models provide, for the first time, the necessary tools to uncover the mechanisms underlying protective immunity, both systemically and

\section{Box 1 | Key remaining questions}

- What are the relative contributions of humoral and cellular responses to protection?

- What are the precise roles of effector and memory B and T-cells, as well as innate immune cells in protection?

- How can an appropriate balance between pro-inflammatory and regulatory responses be achieved, resulting in protection without causing excessive inflammation?

- What are the mechanisms of enduring protection against S. Typhi, S. Paratyphi A, and S. Paratyphi B and how can long-lasting responses be preferentially induced?

- What are the characteristics of protective local gut immune responses?

- What are the differences and similarities between local and systemic immune responses?

- What is the role of the gut microbiota in modulating immune responses against enteric fevers?

- Can cross-reactive immune responses between S. Typhi, S. Paratyphi A, and S. Paratyphi B be exploited to develop broad-spectrum vaccines against enteric fevers? 
in the gut microenvironment. This information will be invaluable in accelerating the development of novel vaccine strategies to prevent enteric fevers. In addition, the expected explosion of knowledge regarding the gut microbiome and its role in modulating immunity to oral vaccines is also likely to provide significant insights in coming years in understanding the observed differences in immunogenicity between vaccine responses in developed and developing countries.

\section{ACKNOWLEDGMENTS}

This work was funded, in part, by NIAID, NIH, DHHS grants R01AI036525, U19 AI082655 (CCHI), U19-AI109776 (CETR), and the Passano Foundation Clinical Investigator Award. The content is solely the responsibility of the authors and does not necessarily represent the official views of the National Institute of Allergy and Infectious Diseases or the National Institutes of Health.

\section{REFERENCES}

1. Levine MM. Typhoid vaccines ready for implementation. N Engl J Med (2009) 361(4):403-5. doi:10.1056/NEJMe0905519

2. Sahastrabuddhe S, Carbis R, Wierzba TF, Ochiai RL. Increasing rates of Salmonella Paratyphi A and the current status of its vaccine development. Expert Rev Vaccines (2013) 12(9):1021-31. doi:10.1586/14760584.2013.825450

3. Levine MM, Ferreccio C, Black RE, Lagos R, San Martin O, Blackwelder WC. Ty21a live oral typhoid vaccine and prevention of paratyphoid fever caused by Salmonella enterica serovar Paratyphi B. Clin Infect Dis (2007) 45(Suppl 1):S24-8. doi:10.1086/518141

4. Alam MM, Tsai LL, Rollins SM, Sheikh A, Khanam F, Bufano MK, et al. Identification of in vivo-induced bacterial proteins during human infection with Salmonella enterica serotype Paratyphi A. Clin Vaccine Immunol (2013) 20(5):712-9. doi:10.1128/cvi.00054-13

5. Arndt MB, Mosites EM, Tian M, Forouzanfar MH, Mokhdad AH, Meller M, et al. Estimating the burden of paratyphoid a in Asia and Africa. PLoS Negl Trop Dis (2014) 8(6):e2925. doi:10.1371/journal.pntd.0002925

6. Gal-Mor O, Suez J, Elhadad D, Porwollik S, Leshem E, Valinsky L, et al. Molecular and cellular characterization of a Salmonella enterica serovar Paratyphi a outbreak strain and the human immune response to infection. Clin Vaccine Immunol (2012) 19(2):146-56. doi:10.1128/cvi.05468-11

7. Teh CS, Chua KH, Thong KL. Paratyphoid fever: splicing the global analyses. Int J Med Sci (2014) 11(7):732-41. doi:10.7150/ijms.7768

8. Levine MM. Typhoid fever vaccines. In: Plotkin SA, Mortimer EA, editors. Vaccines. Philadelphia, PA: W.B. Saunders Company (1994). p. 597-633.

9. Paterson GK, Maskell DJ. Recent advances in the field of Salmonella typhi vaccines. Hum Vaccin (2010) 6(5):379-84. doi:10.4161/hv.6.5.10755

10. Buckle GC, Walker CL, Black RE. Typhoid fever and paratyphoid fever: systematic review to estimate global morbidity and mortality for 2010. J Global Health (2012) 2(1):010401. doi:10.7189/jogh.02.010401

11. Crump JA, Luby SP, Mintz ED. The global burden of typhoid fever. Bull World Health Organ (2004) 82(5):346-53.

12. Ivanoff B, Levine MM, Lambert PH. Vaccination against typhoid fever: present status. Bull World Health Organ (1994) 72(6):957-71.

13. Levine MM, Levine OS. Influence of disease burden, public perception, and other factors on new vaccine development, implementation, and continued use. Lancet (1997) 350(9088):1386-92. doi:10.1016/S0140-6736(97) 03253-4

14. DeRoeck D, Jodar L, Clemens J. Putting typhoid vaccination on the global health agenda. N Engl J Med (2007) 357(11):1069-71. doi:10.1056/ NEJMp078144

15. Connerton P, Wain J, Hien TT, Ali T, Parry C, Chinh NT, et al. Epidemic typhoid in Vietnam: molecular typing of multiple-antibiotic-resistant Salmonella enterica serotype Typhi from four outbreaks. J Clin Microbiol (2000) 38(2):895-7.

16. Rowe B, Ward LR, Threlfall EJ. Multidrug-resistant Salmonella typhi: a worldwide epidemic. Clin Infect Dis (1997) 24(Suppl 1):S106-9. doi:10.1093/clinids/ 24.Supplement_1.S106
17. Petri WA Jr, Miller M, Binder HJ, Levine MM, Dillingham R, Guerrant RL. Enteric infections, diarrhea, and their impact on function and development. J Clin Invest (2008) 118(4):1277-90. doi:10.1172/jci34005

18. Levine MM, Sztein MB. Human mucosal vaccines for Salmonella typhi infections. In: Kiyono H, Ogra PL, McGhee JR, editors. Mucosal Vaccines. SanDiego, CA: Academic Press (1996). p. 201-11.

19. Stuart BM, Pullen RL. Typhoid; clinical analysis of 360 cases. Arch Intern Med (Chic) (1946) 78(6):629-61. doi:10.1001/archinte.1946.00220060002001

20. Mastroeni P, Menager N. Development of acquired immunity to Salmonella. J Med Microbiol (2003) 52(Pt 6):453-9. doi:10.1099/jmm.0.05173-0

21. Dougan G, John V, Palmer S, Mastroeni P. Immunity to salmonellosis. Immunol Rev (2011) 240(1):196-210. doi:10.1111/j.1600-065X.2010.00999.x

22. Marmion DE, Naylor GR, Stewart IO. Second attacks of typhoid fever. J Hyg (Lond) (1953) 51(2):260-7. doi:10.1017/S0022172400015680

23. Hornick RB, Greisman SE, Woodward TE, DuPont HL, Dawkins AT, Snyder MJ. Typhoid fever: pathogenesis and immunologic control. N Engl J Med (1970) 283(13):686-91. doi:10.1056/NEJM197009242831306

24. Tang SW, Abubakar S, Devi S, Puthucheary S, Pang T. Induction and characterization of heat shock proteins of Salmonella typhi and their reactivity with sera from patients with typhoid fever. Infect Immun (1997) 65(7):2983-6.

25. Calderon I, Lobos SR, Rojas HA, Palomino C, Rodriguez LH, Mora GC. Antibodies to porin antigens of Salmonella typhi induced during typhoid infection in humans. Infect Immun (1986) 52(1):209-12.

26. Herath HM. Early diagnosis of typhoid fever by the detection of salivary IgA. J Clin Pathol (2003) 56(9):694-8. doi:10.1136/jcp.56.9.694

27. Jesudason MV, Sridharan G, Arulselvan R, Babu PG, John TJ. Diagnosis of typhoid fever by the detection of anti-LPS \& anti-flagellin antibodies by ELISA. Indian J Med Res (1998) 107:204-7.

28. Ortiz V, Isibasi A, Garcia-Ortigoza E, Kumate J. Immunoblot detection of class-specific humoral immune response to outer membrane proteins isolated from Salmonella typhi in humans with typhoid fever. J Clin Microbiol (1989) 27(7):1640-5.

29. Levine MM, Grados O, Gilman RH, Woodward WE, Solis-Plaza R, Waldman W. Diagnostic value of the Widal test in areas endemic for typhoid fever. Am J Trop Med Hyg (1978) 27(4):795-800.

30. Losonsky GA, Ferreccio C, Kotloff KL, Kaintuck S, Robbins JB, Levine MM. Development and evaluation of an enzyme-linked immunosorbent assay for serum Vi antibodies for detection of chronic Salmonella typhi carriers. J Clin Microbiol (1987) 25(12):2266-9.

31. Sheikh A, Bhuiyan MS, Khanam F, Chowdhury F, Saha A, Ahmed D, et al. Salmonella enterica serovar Typhi-specific immunoglobulin A antibody responses in plasma and antibody in lymphocyte supernatant specimens in Bangladeshi patients with suspected typhoid fever. Clin Vaccine Immunol (2009) 16(11):1587-94. doi:10.1128/CVI.00311-09

32. Sarasombath S, Banchuin N, Sukosol T, Rungpitarangsi B, Manasatit S. Systemic and intestinal immunities after natural typhoid infection. JClin Microbiol (1987) 25(6):1088-93.

33. Pulickal AS, Gautam S, Clutterbuck EA, Thorson S, Basynat B, Adhikari $\mathrm{N}$, et al. Kinetics of the natural, humoral immune response to Salmonella enterica serovar Typhi in Kathmandu, Nepal. Clin Vaccine Immunol (2009) 16(10):1413-9. doi:10.1128/CVI.00245-09

34. Dupont HL, Hornick RB, Snyder MJ, Dawkins AT, Heiner GG, Woodward TE. Studies of immunity in typhoid fever. Protection induced by killed oral antigens or by primary infection. Bull World Health Organ (1971) 44(5):667-72.

35. de Jong R, Altare F, Haagen IA, Elferink DG, Boer T, van Breda Vriesman PJ, et al. Severe mycobacterial and Salmonella infections in interleukin-12 receptordeficient patients. Science (1998) 280(5368):1435-8. doi:10.1126/science.280. 5368.1435

36. Gordon MA. Salmonella infections in immunocompromised adults. J Infect (2008) 56(6):413-22. doi:10.1016/j.jinf.2008.03.012

37. Lammas DA, Casanova JL, Kumararatne DS. Clinical consequences of defects in the IL-12-dependent interferon-gamma (IFN-gamma) pathway. Clin Exp Immunol (2000) 121(3):417-25. doi:10.1046/j.1365-2249.2000.01284.x

38. MacLennan C, Fieschi C, Lammas DA, Picard C, Dorman SE, Sanal O, et al. Interleukin (IL)-12 and IL-23 are key cytokines for immunity against Salmonella in humans. J Infect Dis (2004) 190(10):1755-7. doi:10.1086/425021

39. Dunstan SJ, Stephens HA, Blackwell JM, Duc CM, Lanh MN, Dudbridge F, et al. Genes of the class II and class III major histocompatibility complex are 
associated with typhoid fever in Vietnam. J Infect Dis (2001) 183(2):261-8. doi: $10.1086 / 317940$

40. Gotuzzo E, Frisancho O, Sanchez J, Liendo G, Carrillo C, Black RE, et al. Association between the acquired immunodeficiency syndrome and infection with Salmonella typhi or Salmonella Paratyphi in an endemic typhoid area. Arch Intern Med (1991) 151(2):381-2. doi:10.1001/archinte.1991.00400020125026

41. Dham SK, Thompson RA. Humoral and cell-mediated immune responses in chronic typhoid carriers. Clin Exp Immunol (1982) 50(1):34-40.

42. Dham SK, Thompson RA. Studies of cellular and humoral immunity in typhoid fever and TAB vaccinated subjects. Clin Exp Immunol (1982) 48(2):389-95.

43. Espersen F, Mogensen HH, Hoiby N, Hoj L, Greibe J, Rasmussen SN, et al. Humoral and cellular immunity in typhoid and paratyphoid carrier state, investigated by means of quantitative immunoelectrophoresis and in vitro stimulation of blood lymphocytes. Acta Pathol Microbiol Immunol Scand C (1982) 90(6):293-9.

44. Murphy JR, Baqar S, Munoz C, Schlesinger L, Ferreccio C, Lindberg AA, et al. Characteristics of humoral and cellular immunity to Salmonella typhi in residents of typhoid-endemic and typhoid-free regions. J Infect Dis (1987) 156(6):1005-9. doi:10.1093/infdis/156.6.1005

45. Murphy JR, Wasserman SS, Baqar S, Schlesinger L, Ferreccio C, Lindberg AA, et al. Immunity to Salmonella typhi: considerations relevant to measurement of cellular immunity in typhoid-endemic regions. Clin Exp Immunol (1989) 75(2):228-33.

46. Rajagopalan P, Kumar R, Malaviya AN. Immunological studies in typhoid fever. II. Cell-mediated immune responses and lymphocyte subpopulations in patients with typhoid fever. Clin Exp Immunol (1982) 47(2):269-74.

47. Butler T, Ho M, Acharya G, Tiwari M, Gallati H. Interleukin-6, gamma interferon, and tumor necrosis factor receptors in typhoid fever related to outcome of antimicrobial therapy. Antimicrob Agents Chemother (1993) 37(11):2418-21. doi:10.1128/AAC.37.11.2418

48. Keuter M, Dharmana E, Gasem MH, van der Ven-Jongekrijg J, Djokomoeljanto R, Dolmans WM, et al. Patterns of proinflammatory cytokines and inhibitors during typhoid fever. J Infect Dis (1994) 169(6):1306-11. doi:10.1093/infdis/ 169.6.1306

49. Bhuiyan S, Sayeed A, Khanam F, Leung DT, Rahman Bhuiyan T, Sheikh A, et al. Cellular and cytokine responses to Salmonella enterica serotype Typhi proteins in patients with typhoid fever in Bangladesh. Am J Trop Med Hyg (2014) 90(6):1024-30. doi:10.4269/ajtmh.13-0261

50. Harris JB, Baresch-Bernal A, Rollins SM, Alam A, LaRocque RC, Bikowski $\mathrm{M}$, et al. Identification of in vivo-induced bacterial protein antigens during human infection with Salmonella enterica serovar Typhi. Infect Immun (2006) 74(9):5161-8. doi:10.1128/iai.00488-06

51. Sheikh A, Khanam F, Sayeed MA, Rahman T, Pacek M, Hu Y, et al. Interferongamma and proliferation responses to Salmonella enterica serotype Typhi proteins in patients with S. Typhi bacteremia in Dhaka, Bangladesh. PLoS Negl Trop Dis (2011) 5(6):e1193. doi:10.1371/journal.pntd.0001193

52. Wyant TL, Tanner MK, Sztein MB. Salmonella typhi flagella are potent inducers of proinflammatory cytokine secretion by human monocytes. Infect Immun (1999) 67(7):3619-24.

53. Wyant TL, Tanner MK, Sztein MB. Potent immunoregulatory effects of Salmonella typhi flagella on antigenic stimulation of human peripheral blood mononuclear cells. Infect Immun (1999) 67(3):1338-46.

54. Ekpo P, Sarasombath S, Banchuin N, Pongsunk S, Korbsrisate S, Sirisinha S. Monoclonal antibodies against protein antigens of salmonellae causing paratyphoid fever and their diagnostic application. Asian Pac J Allergy Immunol (1995) 13(1):63-70.

55. Sheikh A, Charles RC, Rollins SM, Harris JB, Bhuiyan MS, Khanam F, et al. Analysis of Salmonella enterica serotype Paratyphi A gene expression in the blood of bacteremic patients in Bangladesh. PLoS Negl Trop Dis (2010) 4(12):e908. doi:10.1371/journal.pntd.0000908

56. Stoycheva M, Murdjeva M. Serum levels of interferon-gamma, interleukin12 , tumour necrosis factor-alpha, and interleukin-10, and bacterial clearance in patients with gastroenteric Salmonella infection. Scand J Infect Dis (2005) 37(1):11-4. doi:10.1080/00365540410026068

57. Pasetti MF, Levine MM, Sztein MB. Animal models paving the way for clinical trials of attenuated Salmonella enterica serovar Typhi live oral vaccines and live vectors. Vaccine (2003) 21(5-6):401-18. doi:10.1016/S0264-410X(02)00472-3
58. de Jong HK, Parry CM, van der Poll T, Wiersinga WJ. Host-pathogen interaction in invasive salmonellosis. PLoS Pathog (2012) 8(10):e1002933. doi:10.1371/journal.ppat.1002933

59. Waddington CS, Darton TC, Woodward WE, Angus B, Levine MM, Pollard AJ. Advancing the management and control of typhoid fever: a review of the historical role of human challenge studies. J Infect (2014) 68(5):405-18. doi:10.1016/j.jinf.2014.01.006

60. Darton TC, Blohmke CJ, Pollard AJ. Typhoid epidemiology, diagnostics and the human challenge model. Curr Opin Gastroenterol (2014) 30(1):7-17. doi:10.1097/mog.0000000000000021

61. Hornick RB, Woodward WE, Greisman SE. Doctor T. E. Woodward's legacy: from typhus to typhoid fever. Clin Infect Dis (2007) 45(Suppl 1):S6-8. doi: $10.1086 / 518138$

62. Greisman SE, Woodward TE, Hornick RB, Snyder MJ, Carozza FA Jr. Typhoid fever: a study of pathogenesis and physiologic abnormalities. Trans Am Clin Climatol Assoc (1961) 73:146-61.

63. Waddington CS, Darton TC, Jones C, Haworth K, Peters A, John T, et al. An outpatient, ambulant-design, controlled human infection model using escalating doses of Salmonella typhi challenge delivered in sodium bicarbonate solution. Clin Infect Dis (2014) 58(9):1230-40. doi:10.1093/cid/ciu078

64. DuPont HL, Hornick RB, Weiss CF, Snyder MJ, Woodward TE. Evaluation of chloramphenicol acid succinate therapy of induced typhoid fever and Rocky Mountain spotted fever. N Engl J Med (1970) 282(2):53-7. doi:10.1056/nejm197001082820201

65. Groschel DH, Hornick RB. Who introduced typhoid vaccination: Almroth Write or Richard Pfeiffer? Rev Infect Dis (1981) 3(6):1251-4. doi:10.1093/ clinids/3.6.1251

66. Guzman CA, Borsutzky S, Griot-Wenk M, Metcalfe IC, Pearman J, Collioud A, et al. Vaccines against typhoid fever. Vaccine (2006) 24(18):3804-11. doi:10.1016/j.vaccine.2005.07.111

67. Levine MM, Ferreccio C, Black RE, Tacket CO, Germanier R. Progress in vaccines against typhoid fever. Rev Infect Dis (1989) 11(Suppl 3):S552-67. doi:10.1093/clinids/11.Supplement_3.S552

68. Ashcroft MT, Ritchie JM, Nicholson CC, Stuart CA. Antibody responses to vaccination of british guyana schoolchildren with heat-killed-phenolized and acetone-killed lyophilized typhoid vaccines. Am J Hyg (1964) 80:221-8.

69. Sur D, Ochiai RL, Bhattacharya SK, Ganguly NK, Ali M, Manna B, et al. A cluster-randomized effectiveness trial of Vi typhoid vaccine in India. $N$ Engl J Med (2009) 361(4):335-44. doi:10.1056/NEJMoa0807521

70. Levine MM, Ferreccio C, Abrego P, Martin OS, Ortiz E, Cryz S. Duration of efficacy of Ty21a, attenuated Salmonella typhi live oral vaccine. Vaccine (1999) 17(Suppl 2):S22-7. doi:10.1016/S0264-410X(99)00231-5

71. Marathe SA, Lahiri A, Negi VD, Chakravortty D. Typhoid fever \& vaccine development: a partially answered question. Indian J Med Res (2012) 135:161-9.

72. Klugman KP, Koornhof HJ, Robbins JB, Le Cam NN. Immunogenicity, efficacy and serological correlate of protection of Salmonella typhi Vi capsular polysaccharide vaccine three years after immunization. Vaccine (1996) 14(5):435-8. doi:10.1016/0264-410X(95)00186-5

73. Sabitha P, Prabha Adhikari MR, Chowdary A, Prabhu M, Soofi M, Shetty M, et al. Comparison of the immunogenicity and safety of two different brands of Salmonella typhi Vi capsular polysaccharide vaccine. Indian J Med Sci (2004) 58(4):141-9.

74. Azze RF, Rodriguez JC, Iniesta MG, Marchena XR, Alfonso VM, Padron FT. Immunogenicity of a new Salmonella Typhi Vi polysaccharide vaccine vax-TyVi - in Cuban school children and teenagers. Vaccine (2003) 21(2122):2758-60. doi:10.1016/S0264-410X(03)00177-4

75. Beeching NJ, Clarke PD, Kitchin NR, Pirmohamed J, Veitch K, Weber F. Comparison of two combined vaccines against typhoid fever and hepatitis A in healthy adults. Vaccine (2004) 23(1):29-35. doi:10.1016/j.vaccine.2004.05.040

76. Yang HH, Kilgore PE, Yang LH, Park JK, Pan YF, Kim Y, et al. An outbreak of typhoid fever, Xing-An County, People's Republic of China, 1999: estimation of the field effectiveness of Vi polysaccharide typhoid vaccine. J Infect Dis (2001) 183(12):1775-80. doi:10.1086/320729

77. Ferreccio C, Levine MM, Rodriguez H, Contreras R. Comparative efficacy of two, three, or four doses of Ty21a live oral typhoid vaccine in enteric-coated capsules: a field trial in an endemic area. J Infect Dis (1989) 159(4):766-9. doi:10.1093/infdis/159.4.766 
78. Forrest BD. Indirect measurement of intestinal immune responses to an orally administered attenuated bacterial vaccine. Infect Immun (1992) 60(5):2023-9.

79. Kantele A. Antibody-secreting cells in the evaluation of the immunogenicity of an oral vaccine. Vaccine (1990) 8(4):321-6. doi:10.1016/0264-410X(90) 90088-4

80. Lundgren A, Kaim J, Jertborn M. Parallel analysis of mucosally derived B- and T-cell responses to an oral typhoid vaccine using simplified methods. Vaccine (2009) 27(33):4529-36. doi:10.1016/j.vaccine.2009.05.005

81. Lundin BS, Johansson C, Svennerholm AM. Oral immunization with a Salmonella enterica serovar Typhi vaccine induces specific circulating mucosahoming $\mathrm{CD} 4(+)$ and CD8(+) $\mathrm{T}$ cells in humans. Infect Immun (2002) 70(10):5622-7. doi:10.1128/IAI.70.10.5622-5627.2002

82. Salerno-Goncalves R, Wahid R, Sztein MB. Ex vivo kinetics of early and longterm multifunctional human leukocyte antigen E-specific CD8+ cells in volunteers immunized with the Ty21a typhoid vaccine. Clin Vaccine Immunol (2010) 17(9):1305-14. doi:10.1128/CVI.00234- 10

83. Salerno-Goncalves R, Wahid R, Sztein MB. Immunization of volunteers with Salmonella enterica serovar Typhi strain Ty21a elicits the oligoclonal expansion of CD8+ T cells with predominant Vbeta repertoires. Infect Immun (2005) 73(6):3521-30. doi:10.1128/IAI.73.6.3521-3530.2005

84. Salerno-Goncalves R, Pasetti MF, Sztein MB. Characterization of CD8(+) effector $\mathrm{T}$ cell responses in volunteers immunized with Salmonella enterica serovar Typhi strain Ty21a typhoid vaccine. J Immunol (2002) 169(4):2196-203. doi:10.4049/jimmunol.169.4.2196

85. Salerno-Goncalves R, Fernandez-Vina M, Lewinsohn DM, Sztein MB. Identification of a human HLA-E-restricted CD8+ T cell subset in volunteers immunized with Salmonella enterica serovar Typhi strain Ty21a typhoid vaccine. Immunol (2004) 173(9):5852-62. doi:10.4049/jimmunol.173.9.5852

86. Tagliabue A, Nencioni L, Caffarena A, Villa L, Boraschi D, Cazzola G, et al. Cellular immunity against Salmonella typhi after live oral vaccine. Clin Exp Immunol (1985) 62:242-7.

87. Tagliabue A, Villa L, De Magistris MT, Romano M, Silvestri S, Boraschi D, et al. IgA-driven T cell-mediated anti-bacterial immunity in man after live oral Ty 21a vaccine. J Immunol (1986) 137(5):1504-10.

88. Viret JF, Favre D, Wegmuller B, Herzog C, Que JU, Cryz SJ Jr, et al. Mucosal and systemic immune responses in humans after primary and booster immunizations with orally administered invasive and noninvasive live attenuated bacteria. Infect Immun (1999) 67(7):3680-5.

89. Wahid R, Pasetti MF, Maciel M Jr, Simon JK, Tacket CO, Levine MM, et al. Oral priming with Salmonella Typhi vaccine strain CVD 909 followed by parenteral boost with the $S$. Typhi Vi capsular polysaccharide vaccine induces CD27+IgD$S$. Typhi-specific IgA and IgG B memory cells in humans. Clin Immunol (2011) 138(2):187-200. doi:10.1016/j.clim.2010.11.006

90. Wahid R, Zafar SJ, McArthur MA, Pasetti MF, Levine MM, Sztein MB. Live oral Salmonella enterica serovar Typhi vaccines Ty21a and CVD 909 induce opsonophagocytic functional antibodies in humans that cross-react with $S$. Paratyphi A and S. Paratyphi B. Clin Vaccine Immunol (2014) 21(3):427-34. doi:10.1128/cvi.00786-13

91. Wahid R, Simon R, Zafar SJ, Levine MM, Sztein MB. Live oral typhoid vaccine Ty21a induces cross-reactive humoral immune responses against Salmonella enterica serovar Paratyphi A and S. Paratyphi B in humans. Clin Vaccine Immunol (2012) 19(6):825-34. doi:10.1128/CVI.00058-12

92. McArthur MA, Sztein MB. Heterogeneity of multifunctional IL-17A producing S. Typhi-specific CD8+ T cells in volunteers following Ty21a typhoid immunization. PloS One (2012) 7(6):e38408. doi:10.1371/journal. pone.0038408

93. Chinnasami B, Mangayarkarasi V, Prema A, Sadasivam K, Davis M. Safety and immunogenicity of Salmonella Typhi Vi conjugate vaccine (Peda Typh) in children up to five years. Int J Sci Res Publ (2013) 3(2):1-5.

94. Szu SC, Klugman KP, Hunt S. Re-examination of immune response and estimation of anti-Vi IgG protective threshold against typhoid fever-based on the efficacy trial of Vi conjugate in young children. Vaccine (2014) 32(20):2359-63 doi:10.1016/j.vaccine.2014.02.050

95. van Damme P, Kafeja F, Anemona A, Basile V, Hilbert AK, De Coster I, et al. Safety, immunogenicity and dose ranging of a new Vi-CRM(1)(9)(7) conjugate vaccine against typhoid fever: randomized clinical testing in healthy adults. PLoS One (2011) 6(9):e25398. doi:10.1371/journal.pone.0025398
96. Lin FY, Ho VA, Khiem HB, Trach DD, Bay PV, Thanh TC, et al. The efficacy of a Salmonella typhi Vi conjugate vaccine in two-to-five-year-old children. N Engl J Med (2001) 344(17):1263-9. doi:10.1056/nejm200104263441701

97. Parry CM, Hien TT, Dougan G, White NJ, Farrar JJ. Typhoid fever. NEngl J Med (2002) 347(22):1770-82. doi:10.1056/NEJMra020201

98. Thiem VD, Lin FY, Canh do G, Son NH, Anh DD, Mao ND, et al. The Vi conjugate typhoid vaccine is safe, elicits protective levels of IgG anti-Vi, and is compatible with routine infant vaccines. Clin Vaccine Immunol (2011) 18(5):730-5. doi:10.1128/cvi.00532-10

99. Canh DG, Lin FY, Thiem VD, Trach DD, Trong ND, Mao ND, et al. Effect of dosage on immunogenicity of a $\mathrm{Vi}$ conjugate vaccine injected twice into 2- to 5-year-old Vietnamese children. Infect Immun (2004) 72(11):6586-8. doi:10.1128/IAI.72.11.6586-6588.2004

100. Research ICoM. Clinical Trials Registry. National Institute of Medical Stetitstics (2014). Available from: http://ctri.nic.in/Clinicaltrials/showallp.php?midl= 4714\&EncHid=\&userName $=$ Vi-TT

101. Simon R, Levine MM. Glycoconjugate vaccine strategies for protection against invasive Salmonella infections. Hum Vaccin Immunother (2012) 8(4):494-8. doi: $10.4161 /$ hv. 19158

102. Cui C, Carbis R, An SJ, Jang H, Czerkinsky C, Szu SC, et al. Physical and chemical characterization and immunologic properties of Salmonella enterica serovar Typhi capsular polysaccharide-diphtheria toxoid conjugates. Clin Vaccine Immunol (2010) 17(1):73-9. doi:10.1128/cvi.00266-09

103. Saha MR, Ramamurthy T, Dutta P, Mitra U. Emergence of Salmonella typhi Vi antigen-negative strains in an epidemic of multidrug-resistant typhoid fever cases in Calcutta, India. Natl Med J India (2000) 13(3):164.

104. Baker S, Sarwar Y, Aziz H, Haque A, Ali A, Dougan G, et al. Detection of Vinegative Salmonella enterica serovar Typhi in the peripheral blood of patients with typhoid fever in the Faisalabad region of Pakistan. J Clin Microbiol (2005) 43(9):4418-25. doi:10.1128/jcm.43.9.4418-4425.2005

105. Tacket CO, Hone DM, Curtiss R III, Kelly SM, Losonsky G, Guers L, et al. Comparison of the safety and immunogenicity of delta aroC delta aroD and delta cya delta crp Salmonella typhi strains in adult volunteers. Infect Immun (1992) 60(2):536-41.

106. Hone DM, Tacket CO, Harris AM, Kay B, Losonsky G, Levine MM. Evaluation in volunteers of a candidate live oral attenuated Salmonella typhi vector vaccine. J Clin Invest (1992) 90(2):412-20.

107. Sztein MB, Wasserman SS, Tacket CO, Edelman R, Hone D, Lindberg AA, et al. Cytokine production patterns and lymphoproliferative responses in volunteers orally immunized with attenuated vaccine strains of Salmonella typhi. J Infect Dis (1994) 170(6):1508-17. doi:10.1093/infdis/170.6.1508

108. Tacket CO, Hone DM, Losonsky GA, Guers L, Edelman R, Levine MM. Clinical acceptability and immunogenicity of CVD 908 Salmonella typhi vaccine strain. Vaccine (1992) 10(7):443-6. doi:10.1016/0264-410X(92)90392-W

109. Tacket CO, Levine MM. CVD 908, CVD 908-htrA, and CVD 909 live oral typhoid vaccines: a logical progression. Clin Infect Dis (2007) 45(Suppl 1):S20-3. doi:10.1086/518135

110. Tacket CO, Sztein MB, Losonsky GA, Wasserman SS, Nataro JP, Edelman R, et al. Safety of live oral Salmonella typhi vaccine strains with deletions in htrA and aroC aroD and immune response in humans. Infect Immun (1997) 65(2):452-6.

111. Tacket CO, Galen J, Sztein MB, Losonsky G, Wyant TL, Nataro J, et al. Safety and immune responses to attenuated Salmonella enterica serovar Typhi oral live vector vaccines expressing tetanus toxin fragment C. Clin Immunol (2000) 97(2):146-53. doi:10.1006/clim.2000.4924

112. Tacket CO, Pasetti MF, Sztein MB, Livio S, Levine MM. Immune responses to an oral typhoid vaccine strain that is modified to constitutively express Vi capsular polysaccharide. J Infect Dis (2004) 190(3):565-70. doi:10.1086/421469

113. Hohmann EL, Oletta CA, Killeen KP, Miller SI. phoP/phoQ-deleted Salmonella typhi (Ty800) is a safe and immunogenic single-dose typhoid fever vaccine in volunteers. J Infect Dis (1996) 173(6):1408-14. doi:10.1093/infdis/173. 6.1408

114. Kirkpatrick BD, Tenney KM, Larsson CJ, O’Neill JP, Ventrone C, Bentley M, et al. The novel oral typhoid vaccine M01ZH09 is well tolerated and highly immunogenic in 2 vaccine presentations. J Infect Dis (2005) 192(3):360-6. doi:10.1086/431605

115. Kirkpatrick BD, Bentley MD, Thern AM, Larsson CJ, Ventrone C, Sreenivasan $\mathrm{MV}$, et al. Comparison of the antibodies in lymphocyte supernatant and antibody-secreting cell assays for measuring intestinal mucosal immune 
response to a novel oral typhoid vaccine (M01ZH09). Clin Diagn Lab Immunol (2005) 12(9):1127-9.

116. Lyon CE, Sadigh KS, Carmolli MP, Harro C, Sheldon E, Lindow JC, et al. In a randomized, double-blinded, placebo-controlled trial, the single oral dose typhoid vaccine, M01ZH09, is safe and immunogenic at doses up to $1.7 \mathrm{x}$ 10(10) colony-forming units. Vaccine (2010) 28(20):3602-8. doi:10.1016/j. vaccine.2010.02.017

117. Tran TH, Nguyen TD, Nguyen TT, Ninh TT, Tran NB, Nguyen VM, et al. A randomised trial evaluating the safety and immunogenicity of the novel single oral dose typhoid vaccine M01ZH09 in healthy Vietnamese children. PLoS One (2010) 5(7):e11778. doi:10.1371/journal.pone.0011778

118. Lindow JC, Fimlaid KA, Bunn JY, Kirkpatrick BD. Antibodies in action: role of human opsonins in killing Salmonella enterica serovar Typhi. Infect Immun (2011) 79(8):3188-94. doi:10.1128/IAI.05081-11

119. Hindle Z, Chatfield SN, Phillimore J, Bentley M, Johnson J, Cosgrove CA, et al. Characterization of Salmonella enterica derivatives harboring defined aroC and Salmonella pathogenicity island 2 type III secretion system (ssaV) mutations by immunization of healthy volunteers. Infect Immun (2002) 70(7):3457-67. doi:10.1128/IAI.70.7.3457-3467.2002

120. Kirkpatrick BD, McKenzie R, O’Neill JP, Larsson CJ, Bourgeois AL, Shimko J, et al. Evaluation of Salmonella enterica serovar Typhi (Ty2 aroC-ssaV-) M01ZH09, with a defined mutation in the Salmonella pathogenicity island 2, as a live, oral typhoid vaccine in human volunteers. Vaccine (2006) 24(2):116-23. doi:10.1016/j.vaccine.2005.08.008

121. Salerno-Goncalves R, Wyant TL, Pasetti MF, Fernandez-Vina M, Tacket $\mathrm{CO}$, Levine MM, et al. Concomitant induction of CD4(+) and CD8(+) T cell responses in volunteers immunized with Salmonella enterica serovar Typhi strain CVD 908-htrA. J Immunol (2003) 170(5):2734-41. doi:10.4049/ jimmunol.170.5.2734

122. Sztein MB, Tanner MK, Polotsky Y, Orenstein JM, Levine MM. Cytotoxic T lymphocytes after oral immunization with attenuated vaccine strains of Salmonella typhi in humans. J Immunol (1995) 155(8):3987-93.

123. Wahid R, Salerno-Goncalves R, Tacket CO, Levine MM, Sztein MB. Cellmediated immune responses in humans after immunization with one or two doses of oral live attenuated typhoid vaccine CVD 909. Vaccine (2007) 25(8):1416-25. doi:10.1016/j.vaccine.2006.10.040

124. Roland KL, Tinge SA, Kochi SK, Thomas LJ, Killeen KP. Reactogenicity and immunogenicity of live attenuated Salmonella enterica serovar Paratyphi A enteric fever vaccine candidates. Vaccine (2010) 28(21):3679-87. doi:10.1016/ j.vaccine.2010.03.019

125. Gat O, Galen JE, Tennant S, Simon R, Blackwelder WC, Silverman DJ, et al. Cell-associated flagella enhance the protection conferred by mucosallyadministered attenuated Salmonella Paratyphi A vaccines. PLoS Negl Trop Dis (2011) 5(11):e1373. doi:10.1371/journal.pntd.0001373

126. Micoli F, Rondini S, Gavini M, Lanzilao L, Medaglini D, Saul A, et al. O:2CRM(197) conjugates against Salmonella Paratyphi A. PLoS One (2012) 7(11):e47039. doi:10.1371/journal.pone.0047039

127. Galen JE, Pasetti MF, Tennant S, Ruiz-Olvera P, Sztein MB, Levine MM. Salmonella enterica serovar Typhi live vector vaccines finally come of age. Immunol Cell Biol (2009) 87(5):400-12. doi:10.1038/icb.2009.31

128. Frey SE, Lottenbach KR, Hill H, Blevins TP, Yu Y, Zhang Y, et al. A phase I, doseescalation trial in adults of three recombinant attenuated Salmonella Typhi vaccine vectors producing Streptococcus pneumoniae surface protein antigen PspA. Vaccine (2013) 31(42):4874-80. doi:10.1016/j.vaccine.2013.07.049

129. Gonzalez C, Hone D, Noriega FR, Tacket CO, Davis JR, Losonsky G, et al. Salmonella typhi vaccine strain CVD 908 expressing the circumsporozoite protein of Plasmodium falciparum: strain construction and safety and immunogenicity in humans. J Infect Dis (1994) 169(4):927-31. doi:10.1093/infdis/169. 4.927

130. Khan S, Chatfield S, Stratford R, Bedwell J, Bentley M, Sulsh S, et al. Ability of SPI2 mutant of $S$. typhi to effectively induce antibody responses to the mucosal antigen enterotoxigenic $E$. coli heat labile toxin B subunit after oral delivery to humans. Vaccine (2007) 25(21):4175-82. doi:10.1016/j.vaccine. 2007.03.007

131. Nardelli-Haefliger D, Kraehenbuhl JP, Curtiss R III, Schodel F, Potts A, Kelly $\mathrm{S}$, et al. Oral and rectal immunization of adult female volunteers with a recombinant attenuated Salmonella typhi vaccine strain. Infect Immun (1996) 64(12):5219-24.
132. DiPetrillo MD, Tibbetts T, Kleanthous H, Killeen KP, Hohmann EL. Safety and immunogenicity of phoP/phoQ-deleted Salmonella typhi expressing Helicobacter pylori urease in adult volunteers. Vaccine (1999) 18(5-6):449-59. doi:10.1016/S0264-410X(99)00246-7

133. Metzger WG, Mansouri E, Kronawitter M, Diescher S, Soerensen M, Hurwitz $\mathrm{R}$, et al. Impact of vector-priming on the immunogenicity of a live recombinant Salmonella enterica serovar Typhi Ty2la vaccine expressing urease A and B from Helicobacter pylori in human volunteers. Vaccine (2004) 22(1718):2273-7. doi:10.1016/j.vaccine.2003.11.020

134. Bumann D, Holland P, Siejak F, Koesling J, Sabarth N, Lamer S, et al. A Comparison of murine and human immunoproteomes of Helicobacter pylori validates the preclinical murine infection model for antigen screening. Infect Immun (2002) 70(11):6494-8. doi:10.1128/IAI.70.11.6494-6498.2002

135. Kilhamn J, Lundin SB, Brevinge H, Svennerholm AM, Jertborn M. T- and B-cell immune responses of patients who had undergone colectomies to oral administration of Salmonella enterica serovar Typhi Ty21a vaccine. Clin Diagn Lab Immunol (2003) 10(3):426-30.

136. Salazar-Gonzalez RM, Maldonado-Bernal C, Ramirez-Cruz NE, RiosSarabia N, Beltran-Nava J, Castanon-Gonzalez J, et al. Induction of cellular immune response and anti-Salmonella enterica serovar Typhi bactericidal antibodies in healthy volunteers by immunization with a vaccine candidate against typhoid fever. Immunol Lett (2004) 93(2-3):115-22. doi:10.1016/j.imlet.2004. 01.010

137. Pasetti MF, Simon JK, Sztein MB, Levine MM. Immunology of gut mucosal vaccines. Immunol Rev (2011) 239(1):125-48. doi:10.1111/j.1600-065X.2010. 00970.x

138. Sztein MB. Cell-mediated immunity and antibody responses elicited by attenuated Salmonella enterica serovar Typhi strains used as live oral vaccines in humans. Clin Infect Dis (2007) 45(Suppl 1):S15-9. doi:10.1086/518140

139. Tacket CO, Ferreccio C, Robbins JB, Tsai CM, Schulz D, Cadoz M, et al. Safety and immunogenicity of two Salmonella typhi Vi capsular polysaccharide vaccines. J Infect Dis (1986) 154(2):342-5. doi:10.1093/infdis/154.2.342

140. Tacket CO, Sztein MB, Wasserman SS, Losonsky G, Kotloff KL, Wyant TL, et al. Phase 2 clinical trial of attenuated Salmonella enterica serovar Typhi oral live vector vaccine CVD 908-htrA in U.S. volunteers. Infect Immun (2000) 68(3):1196-201. doi:10.1128/IAI.68.3.1196-1201.2000

141. Hornick RB, Greisman SE, Woodward TE, DuPont HL, Dawkins AT, Snyder MJ. Typhoid fever: pathogenesis and immunologic control. 2. N Engl J Med (1970) 283(14):739-46. doi:10.1056/NEJM197010012831406

142. Raffatellu M, Chessa D, Wilson RP, Tukel C, Akcelik M, Baumler AJ. Capsulemediated immune evasion: a new hypothesis explaining aspects of typhoid fever pathogenesis. Infect Immun (2006) 74(1):19-27. doi:10.1128/IAI.74.1. 19-27.2006

143. Wangdi T, Lee CY, Spees AM, Yu C, Kingsbury DD, Winter SE, et al. The Vi capsular polysaccharide enables Salmonella enterica serovar Typhi to evade microbe-guided neutrophil chemotaxis. PLoS Pathog (2014) 10(8):e1004306. doi:10.1371/journal.ppat.1004306

144. Levine MM, Tacket CO, Sztein MB. Host-Salmonella interaction: human trials. Microbes Infect (2001) 3(14-15):1271-9. doi:10.1016/S1286-4579(01)01487-3

145. Cancellieri V, Fara GM. Demonstration of specific IgA in human feces after immunization with live Ty21a Salmonella typhi vaccine. J Infect Dis (1985) 151(3):482-4. doi:10.1093/infdis/151.3.482

146. Pakkanen SH, Kantele JM, Moldoveanu Z, Hedges S, Hakkinen M, Mestecky J, et al. Expression of homing receptors on IgA1 and IgA2 plasmablasts in blood reflects differential distribution of IgA1 and IgA2 in various body fluids. Clin Vaccine Immunol (2010) 17(3):393-401. doi:10.1128/CVI.00475-09

147. Schroeder HW Jr, Cavacini L. Structure and function of immunoglobulins. J Allergy Clin Immunol (2010) 125(2 Suppl 2):S41-52. doi:10.1016/j.jaci.2009. 09.046

148. Persson MA, Ekwall E, Hammarstrom L, Lindberg AA, Smith CI. Immunoglobulin G (IgG) and IgA subclass pattern of human antibodies to Shigella flexneri and Salmonella serogroup B and D lipopolysaccharide $\mathrm{O}$ antigens. Infect Immun (1986) 52(3):834-9.

149. Mittrucker HW, Raupach B, Kohler A, Kaufmann SH. Cutting edge: role of B lymphocytes in protective immunity against Salmonella typhimurium infection. J Immunol (2000) 164(4):1648-52. doi:10.4049/jimmunol.164.4.1648

150. de Wit J, Souwer Y, Jorritsma T, Klaasse Bos H, ten Brinke A, Neefjes J, et al. Antigen-specific B cells reactivate an effective cytotoxic $\mathrm{T}$ cell response 
against phagocytosed Salmonella through cross-presentation. PLoS One (2010) 5(9):e13016. doi:10.1371/journal.pone.0013016

151. Salerno-Goncalves R, Rezwan T, Sztein MB. B cells modulate mucosal associated invariant T cell immune responses. Front Immunol (2014) 4:511. doi:10.3389/fimmu.2013.00511

152. Wahid R, Salerno-Goncalves R, Tacket CO, Levine MM, Sztein MB. Generation of specific effector and memory $\mathrm{T}$ cells with gut- and secondary lymphoid tissue-homing potential by oral attenuated CVD 909 typhoid vaccine in humans. Mucosal Immunol (2008) 1(5):389-98. doi:10.1038/mi.2008.30

153. Tarlinton D, Radbruch A, Hiepe F, Dorner T. Plasma cell differentiation and survival. Curr Opin Immunol (2008) 20(2):162-9. doi:10.1016/j.coi.2008.03.016

154. Kantele A, Kantele JM, Savilahti E, Westerholm M, Arvilommi H, Lazarovits A, et al. Homing potentials of circulating lymphocytes in humans depend on the site of activation: oral, but not parenteral, typhoid vaccination induces circulating antibody-secreting cells that all bear homing receptors directing them to the gut. J Immunol (1997) 158(2):574-9.

155. Kantele A, Pakkanen SH, Karttunen R, Kantele JM. Head-to-head comparison of humoral immune responses to Vi capsular polysaccharide and Salmonella Typhi Ty21a typhoid vaccines - a randomized trial. PLoS One (2013) 8(4):e60583. doi:10.1371/journal.pone.0060583

156. Penttila IA, Gibson CE, Leong AY, Zola H, LaBrooy JT. Cell surface determinants on typhoid-specific B cells isolated from peripheral blood after oral Ty21a typhoid vaccination in humans. Immunol Cell Biol (1995) 73(3):198-204. doi:10.1038/icb.1995.33

157. Kantele A, Westerholm M, Kantele JM, Makela PH, Savilahti E. Homing potentials of circulating antibody-secreting cells after administration of oral or parenteral protein or polysaccharide vaccine in humans. Vaccine (1999) 17(3):229-36. doi:10.1016/S0264-410X(98)00193-5

158. Kantele A. Peripheral blood antibody-secreting cells in the evaluation of the immune response to an oral vaccine. J Biotechnol (1996) 44(1-3):217-24. doi:10.1016/0168-1656(95)00134-4

159. Kantele A, Arvilommi H, Kantele JM, Rintala L, Makela PH. Comparison of the human immune response to live oral, killed oral or killed parenteral Salmonella typhi TY21A vaccines. Microb Pathog (1991) 10(2):117-26. doi:10.1016/0882-4010(91)90072-I

160. Levine MM, Sztein MB. Vaccine development strategies for improving immunization: the role of modern immunology. Nat Immunol (2004) 5(5):460-4. doi:10.1038/ni0504-460

161. Takemori T, Kaji T, Takahashi Y, Shimoda M, Rajewsky K. Generation of memory B cells inside and outside germinal centers. Eur J Immunol (2014) 44(5):1258-64. doi:10.1002/eji.201343716

162. Maecker HT, McCoy JP, Nussenblatt R. Standardizing immunophenotyping for the Human Immunology Project. Nat Rev Immunol (2012) 12(3):191-200. doi: $10.1038 /$ nri3158

163. Tangye SG, Good KL. Human IgM+CD27+ B cells: memory B cells or "memory” B cells? J Immunol (2007) 179(1):13-9. doi:10.4049/jimmunol.179.1.13

164. Perez-Shibayama C, Gil-Cruz C, Pastelin-Palacios R, Cervantes-Barragan L, Hisaki E, Chai Q, et al. IFN-gamma-producing CD4+ T cells promote generation of protective germinal center-derived IgM+ B cell memory against Salmonella Typhi. J Immunol (2014) 192(11):5192-200. doi:10.4049/jimmunol 1302526

165. Toapanta FR, Bernal PJ, Sztein MB. Diverse phosphorylation patterns of B cell receptor-associated signaling in naive and memory human B cells revealed by phosphoflow, a powerful technique to study signaling at the single cell level. Front Cell Infect Microbiol (2012) 2:128. doi:10.3389/fcimb.2012.00128

166. Bouvet JP, Decroix N, Pamonsinlapatham P. Stimulation of local antibody production: parenteral or mucosal vaccination? Trends Immunol (2002) 23(4):209-13. doi:10.1016/S1471-4906(02)02186-5

167. Mora JR, Iwata M, Eksteen B, Song SY, Junt T, Senman B, et al. Generation of gut-homing IgA-secreting B cells by intestinal dendritic cells. Science (2006) 314(5802):1157-60. doi:10.1126/science.1132742

168. Lazarus NH, Kunkel EJ, Johnston B, Wilson E, Youngman KR, Butcher EC. A common mucosal chemokine (mucosae-associated epithelial chemokine/CCL28) selectively attracts IgA plasmablasts. J Immunol (2003) 170(7):3799-805. doi:10.4049/jimmunol.170.7.3799

169. Kantele A, Savilahti E, Tiimonen H, Iikkanen K, Autio S, Kantele JM. Cutaneous lymphocyte antigen expression on human effector B cells depends on the site and on the nature of antigen encounter. Eur J Immunol (2003) 33(12):3275-83. doi:10.1002/eji.200324311
170. Sundstrom P, Lundin SB, Nilsson LA, Quiding-Jarbrink M. Human IgAsecreting cells induced by intestinal, but not systemic, immunization respond to CCL25 (TECK) and CCL28 (MEC). Eur J Immunol (2008) 38(12):3327-38. doi:10.1002/eji.200838506

171. Salerno-Goncalves R, Sztein MB. Cell-mediated immunity and the challenges for vaccine development. Trends Microbiol (2006) 14(12):536-42. doi:10.1016/ j.tim.2006.10.004

172. Eloe-Fadrosh EA, McArthur MA, Seekatz AM, Drabek EF, Rasko DA, Sztein $\mathrm{MB}$, et al. Impact of oral typhoid vaccination on the human gut microbiota and correlations with $S$. Typhi-specific immunological responses. PLoS One (2013) 8(4):e62026. doi:10.1371/journal.pone.0062026

173. Cohen JJ. Programmed cell death in the immune system. Adv Immunol (1991) 50:55-85. doi:10.1016/S0065-2776(08)60822-6

174. Golstein P, Ojcius DM, Young JD. Cell death mechanisms and the immune system. Immunol Rev (1991) 121:29-65. doi:10.1111/j.1600-065X.1991.tb00822.x

175. Kerr JF, Wyllie AH, Currie AR. Apoptosis: a basic biological phenomenon with wide-ranging implications in tissue kinetics. Br J Cancer (1972) 26(4):239-57. doi:10.1038/bjc.1972.33

176. Kagi D, Ledermann B, Burki K, Zinkernagel RM, Hengartner H. Molecular mechanisms of lymphocyte-mediated cytotoxicity and their role in immunological protection and pathogenesis in vivo. Annu Rev Immunol (1996) 14:207-32. doi:10.1146/annurev.immunol.14.1.207

177. Hanabuchi S, Koyanagi M, Kawasaki A, Shinohara N, Matsuzawa A, Nishimura $\mathrm{Y}$, et al. Fas and its ligand in a general mechanism of T-cell-mediated cytotoxicity. Proc Natl Acad Sci U S A (1994) 91(11):4930-4. doi:10.1073/pnas. 91.11.4930

178. Sallusto F, Geginat J, Lanzavecchia A. Central memory and effector memory T cell subsets: function, generation, and maintenance. Annu Rev Immunol (2004) 22:745-63. doi:10.1146/annurev.immunol.22.012703.104702

179. Sallusto F, Lenig D, Forster R, Lipp M, Lanzavecchia A. Two subsets of memory T lymphocytes with distinct homing potentials and effector functions. Nature (1999) 401(6754):708-12. doi:10.1038/44385

180. Precopio ML, Betts MR, Parrino J, Price DA, Gostick E, Ambrozak DR, et al. Immunization with vaccinia virus induces polyfunctional and phenotypically distinctive CD8(+) T cell responses. J Exp Med (2007) 204(6):1405-16. doi:10.1084/jem.20062363

181. Betts MR, Brenchley JM, Price DA, De Rosa SC, Douek DC, Roederer M, et al. Sensitive and viable identification of antigen-specific CD8+ T cells by a flow cytometric assay for degranulation. J Immunol Methods (2003) 281(12):65-78. doi:10.1016/S0022-1759(03)00265-5

182. Betts MR, Nason MC, West SM, De Rosa SC, Migueles SA, Abraham J, et al. HIV nonprogressors preferentially maintain highly functional HIV-specific CD8+ T cells. Blood (2006) 107(12):4781-9. doi:10.1182/blood-2005-12-4818

183. Caccamo N, Guggino G, Joosten SA, Gelsomino G, Di Carlo P, Titone L, et al. Multifunctional CD4(+) T cells correlate with active Mycobacterium tuberculosis infection. Eur J Immunol (2010) 40(8):2211-20. doi:10.1002/eji. 201040455

184. Qiu Z, Zhang M, Zhu Y, Zheng F, Lu P, Liu H, et al. Multifunctional CD4 $\mathrm{T}$ cell responses in patients with active tuberculosis. Sci Rep (2012) 2:216. doi:10.1038/srep00216

185. Johanns TM, Ertelt JM, Rowe JH, Way SS. Regulatory T cell suppressive potency dictates the balance between bacterial proliferation and clearance during persistent Salmonella infection. PLoS Pathog (2010) 6(8):e1001043. doi:10.1371/journal.ppat.1001043

186. Sakaguchi S, Wing K, Onishi Y, Prieto-Martin P, Yamaguchi T. Regulatory T cells: how do they suppress immune responses? Int Immunol (2009) 21(10):1105-11. doi:10.1093/intimm/dxp095

187. Su LF, Kidd BA, Han A, Kotzin JJ, Davis MM. Virus-specific CD4(+) memoryphenotype $\mathrm{T}$ cells are abundant in unexposed adults. Immunity (2013) 38(2):373-83. doi:10.1016/j.immuni.2012.10.021

188. Ergin A, Syrbe U, Scheer R, Thiel A, Adam T, Bussow K, et al. Impaired peripheral Th1 CD4+ T cell response to Escherichia coli proteins in patients with Crohn's disease and ankylosing spondylitis. J Clin Immunol (2011) 31(6):998-1009. doi:10.1007/s10875-011-9575-x

189. Macpherson A, Khoo UY, Forgacs I, Philpott-Howard J, Bjarnason I. Mucosal antibodies in inflammatory bowel disease are directed against intestinal bacteria. Gut (1996) 38(3):365-75. doi:10.1136/gut.38.3.365

190. Belkaid Y, Hand TW. Role of the microbiota in immunity and inflammation. Cell (2014) 157(1):121-41. doi:10.1016/j.cell.2014.03.011 
191. Nyirenda TS, Seeley AE, Mandala WL, Drayson MT, MacLennan CA. Early interferon-gamma production in human lymphocyte subsets in response to nontyphoidal Salmonella demonstrates inherent capacity in innate cells. PLoS One (2010) 5(10):e13667. doi:10.1371/journal.pone.0013667

192. Dusseaux M, Martin E, Serriari N, Peguillet I, Premel V, Louis D, et al. Human MAIT cells are xenobiotic-resistant, tissue-targeted, CD161hi IL-17-secreting T cells. Blood (2011) 117(4):1250-9. doi:10.1182/blood-2010-08-303339

193. Le Bourhis L, Guerri L, Dusseaux M, Martin E, Soudais C, Lantz O. Mucosalassociated invariant T cells: unconventional development and function. Trends Immunol (2011) 32(5):212-8. doi:10.1016/j.it.2011.02.005

194. Wakao H, Yoshikiyo K, Koshimizu U, Furukawa T, Enomoto K, Matsunaga T, et al. Expansion of functional human mucosal-associated invariant $\mathrm{T}$ cells via reprogramming to pluripotency and redifferentiation. Cell Stem Cell (2013) 12(5):546-58. doi:10.1016/j.stem.2013.03.001

195. Cosgrove C, Ussher JE, Rauch A, Gartner K, Kurioka A, Huhn MH, et al. Early and nonreversible decrease of CD161++/MAIT cells in HIV infection. Blood (2013) 121(6):951-61. doi:10.1182/blood-2012-06-436436

196. Leeansyah E, Ganesh A, Quigley MF, Sonnerborg A, Andersson J, Hunt PW, et al. Activation, exhaustion, and persistent decline of the antimicrobial MR1restricted MAIT-cell population in chronic HIV-1 infection. Blood (2013) 121(7):1124-35. doi:10.1182/blood-2012-07-445429

197. Sundquist M, Rydstrom A, Wick MJ. Immunity to Salmonella from a dendritic point of view. Cell Microbiol (2004) 6(1):1-11. doi:10.1046/j.1462-5822.2003. 00336.x

198. Segura E, Amigorena S. Cross-presentation by human dendritic cell subsets. Immunol Lett (2014) 158(1-2):73-8. doi:10.1016/j.imlet.2013.12.001

199. Albert ML, Sauter B, Bhardwaj N. Dendritic cells acquire antigen from apoptotic cells and induce class I-restricted CTLs. Nature (1998) 392(6671):86-9. doi: $10.1038 / 32183$

200. Fehres CM, Unger WW, Garcia-Vallejo JJ, van Kooyk Y. Understanding the biology of antigen cross-presentation for the design of vaccines against cancer. Front Immunol (2014) 5:149. doi:10.3389/fimmu.2014.00149

201. Salerno-Goncalves R, Sztein MB. Priming of Salmonella enterica serovar Typhispecific CD8(+) T cells by suicide dendritic cell cross-presentation in humans. PLoS One (2009) 4(6):e5879. doi:10.1371/journal.pone.0005879

202. Mastroeni P, Harrison JA, Robinson JH, Clare S, Khan S, Maskell DJ, et al. Interleukin-12 is required for control of the growth of attenuated aromaticcompound-dependent salmonellae in $\mathrm{BALB} / \mathrm{c}$ mice: role of gamma interferon and macrophage activation. Infect Immun (1998) 66(10):4767-76.

203. Hess J, Ladel C, Miko D, Kaufmann SH. Salmonella typhimurium aroA- infection in gene-targeted immunodeficient mice: major role of CD4+ TCR-alpha beta cells and IFN-gamma in bacterial clearance independent of intracellular location. J Immunol (1996) 156(9):3321-6.

204. Brandtzaeg P, Farstad IN, Haraldsen G. Regional specialization in the mucosal immune system: primed cells do not always home along the same track. Immunol Today (1999) 20(6):267-77. doi:10.1016/S0167-5699(99)01468-1

205. Butcher EC, Williams M, Youngman K, Rott L, Briskin M. Lymphocyte trafficking and regional immunity. Adv Immunol (1999) 72:209-53. doi:10.1016/ S0065-2776(08)60022-X

206. Kunkel EJ, Campbell JJ, Haraldsen G, Pan J, Boisvert J, Roberts AI, et al. Lymphocyte CC chemokine receptor 9 and epithelial thymus-expressed chemokine (TECK) expression distinguish the small intestinal immune compartment: epithelial expression of tissue-specific chemokines as an organizing principle in regional immunity. J Exp Med (2000) 192(5):761-8. doi:10.1084/jem.192.5.761

207. Hamann A, Andrew DP, Jablonski-Westrich D, Holzmann B, Butcher EC. Role of alpha 4-integrins in lymphocyte homing to mucosal tissues in vivo. J Immunol (1994) 152(7):3282-93.

208. Kantele A, Zivny J, Hakkinen M, Elson CO, Mestecky J. Differential homing commitments of antigen-specific $\mathrm{T}$ cells after oral or parenteral immunization in humans. J Immunol (1999) 162(9):5173-7.

209. Svensson M, Marsal J, Ericsson A, Carramolino L, Broden T, Marquez G, et al. CCL25 mediates the localization of recently activated CD8alphabeta $(+)$ lymphocytes to the small-intestinal mucosa. J Clin Invest (2002) 110(8):1113-21. doi:10.1172/JCI0215988

210. Agace WW, Higgins JM, Sadasivan B, Brenner MB, Parker CM. T-lymphocyteepithelial-cell interactions: integrin alpha(E)(CD103)beta(7), LEEP-CAM and chemokines. Curr Opin Cell Biol (2000) 12(5):563-8. doi:10.1016/S09550674(00)00132-0
211. Ferreira RB, Antunes LC, Finlay BB. Should the human microbiome be considered when developing vaccines? PLoS Pathog (2010) 6(11):e1001190. doi:10.1371/journal.ppat.1001190

212. John TJ. Experience with poliovaccines in the control of poliomyelitis in India. Public Health Rev (1993) 21(1-2):83-90.

213. Patriarca PA, Wright PF, John TJ. Factors affecting the immunogenicity of oral poliovirus vaccine in developing countries: review. Rev Infect Dis (1991) 13(5):926-39. doi:10.1093/clinids/13.5.926

214. Lagos R, Fasano A, Wasserman SS, Prado V, San Martin O, Abrego P, et al. Effect of small bowel bacterial overgrowth on the immunogenicity of single-dose live oral cholera vaccine CVD 103-HgR. J Infect Dis (1999) 180(5):1709-12. doi:10.1086/315051

215. Lopman BA, Pitzer VE, Sarkar R, Gladstone B, Patel M, Glasser J, et al. Understanding reduced rotavirus vaccine efficacy in low socio-economic settings. PLoS One (2012) 7(8):e41720. doi:10.1371/journal.pone.0041720

216. Cooper PJ, Chico ME, Losonsky G, Sandoval C, Espinel I, Sridhara R, et al. Albendazole treatment of children with ascariasis enhances the vibriocidal antibody response to the live attenuated oral cholera vaccine CVD 103-HgR. J Infect Dis (2000) 182(4):1199-206. doi:10.1086/315837

217. Muhsen K, Pasetti MF, Reymann MK, Graham DY, Levine MM. Helicobacter pylori infection affects immune responses following vaccination of typhoidnaive U.S. adults with attenuated Salmonella typhi oral vaccine CVD 908-htrA. J Infect Dis (2014) 209(9):1452-8. doi:10.1093/infdis/jit625

218. Bhan MK, Bahl R, Sazawal S, Sinha A, Kumar R, Mahalanabis D, et al. Association between Helicobacter pylori infection and increased risk of typhoid fever J Infect Dis (2002) 186(12):1857-60. doi:10.1086/345762

219. Suerbaum S, Michetti P. Helicobacter pylori infection. N Engl J Med (2002) 347(15):1175-86. doi:10.1056/NEJMra020542

220. Benyacoub J, Rochat F, Saudan KY, Rochat I, Antille N, Cherbut C, et al. Feeding a diet containing a fructooligosaccharide mix can enhance Salmonella vaccine efficacy in mice. J Nutr (2008) 138(1):123-9.

221. Fang H, Elina T, Heikki A, Seppo S. Modulation of humoral immune response through probiotic intake. FEMS Immunol Med Microbiol (2000) 29(1):47-52. doi:10.1111/j.1574-695X.2000.tb01504.X

222. Pakkanen SH, Kantele JM, Kantele A. Cross-reactive gut-directed immune response against Salmonella enterica serovar Paratyphi A and B in typhoid fever and after oral Ty2 1a typhoid vaccination. Vaccine (2012) 30(42):6047-53. doi:10.1016/j.vaccine.2012.07.051

223. Pakkanen SH, Kantele JM, Kantele A. Cross-reactive immune response induced by the Vi capsular polysaccharide typhoid vaccine against Salmonella Paratyphi strains. Scand J Immunol (2014) 79(3):222-9. doi:10.1111/sji.12151

224. Kantele A, Pakkanen SH, Siitonen A, Karttunen R, Kantele JM. Live oral typhoid vaccine Salmonella Typhi Ty21a - a surrogate vaccine against nontyphoid salmonella? Vaccine (2012) 30(50):7238-45. doi:10.1016/j.vaccine. 2012.10.002

225. Pakkanen SH, Kantele JM, Herzog C, Kantele A. Cross-reactive immune response elicited by parenteral $\mathrm{Vi}$ polysaccharide typhoid vaccine against nontyphoid salmonellae. Vaccine (2014) 32(5):544-51. doi:10.1016/j.vaccine.2013. 12.001

226. Charles RC, Sheikh A, Krastins B, Harris JB, Bhuiyan MS, LaRocque $\mathrm{RC}$, et al. Characterization of anti-Salmonella enterica serotype Typhi antibody responses in bacteremic Bangladeshi patients by an immunoaffinity proteomics-based technology. Clin Vaccine Immunol (2010) 17(8):1188-95. doi:10.1128/CVI.00104-10

227. Liang L, Juarez S, Nga TV, Dunstan S, Nakajima-Sasaki R, Davies DH, et al. Immune profiling with a Salmonella Typhi antigen microarray identifies new diagnostic biomarkers of human typhoid. Sci Rep (2013) 3:1043. doi:10.1038/srep01043

228. Thompson LJ, Dunstan SJ, Dolecek C, Perkins T, House D, Dougan G, et al. Transcriptional response in the peripheral blood of patients infected with Salmonella enterica serovar Typhi. Proc Natl Acad Sci U S A (2009) 106(52):22433-8. doi:10.1073/pnas.0912386106

229. Lee SJ, Liang L, Juarez S, Nanton MR, Gondwe EN, Msefula CL, et al Identification of a common immune signature in murine and human systemic salmonellosis. Proc Natl Acad Sci U S A (2012) 109(13):4998-5003. doi:10.1073/pnas.1111413109

230. Bandura DR, Baranov VI, Ornatsky OI, Antonov A, Kinach R, Lou X, et al. Mass cytometry: technique for real time single cell multitarget immunoassay 
based on inductively coupled plasma time-of-flight mass spectrometry. Anal Chem (2009) 81(16):6813-22. doi:10.1021/ac901049w

231. Bendall SC, Simonds EF, Qiu P, Amir el AD, Krutzik PO, Finck R, et al. Single-cell mass cytometry of differential immune and drug responses across a human hematopoietic continuum. Science (2011) 332(6030):687-96. doi:10. $1126 /$ science. 1198704

232. Bjornson ZB, Nolan GP, Fantl WJ. Single-cell mass cytometry for analysis of immune system functional states. Curr Opin Immunol (2013) 25(4):484-94. doi:10.1016/j.coi.2013.07.004

Conflict of Interest Statement: The authors declare that the research was conducted in the absence of any commercial or financial relationships that could be construed as a potential conflict of interest.
Received: 29 July 2014; paper pending published: 12 September 2014; accepted: 03 October 2014; published online: 27 October 2014.

Citation: Sztein MB, Salerno-Goncalves R and McArthur MA (2014) Complex adaptive immunity to enteric fevers in humans: lessons learned and the path forward. Front. Immunol. 5:516. doi: 10.3389/fimmu.2014.00516

This article was submitted to Microbial Immunology, a section of the journal Frontiers in Immunology.

Copyright () 2014 Sztein, Salerno-Goncalves and McArthur. This is an open-access article distributed under the terms of the Creative Commons Attribution License (CC $B Y)$. The use, distribution or reproduction in other forums is permitted, provided the original author(s) or licensor are credited and that the original publication in this journal is cited, in accordance with accepted academic practice. No use, distribution or reproduction is permitted which does not comply with these terms. 